\title{
Household anaerobic digesters for biogas production in Latin
}

\section{America: a review}

\author{
Marianna Garfí1,*, Jaime Martí-Herrero ${ }^{2,3}$, Anna Garwood ${ }^{4}$, Ivet Ferrer ${ }^{1}$
}

${ }^{1}$ Group of Environmental Engineering and Microbiology (GEMMA), Department of Civil and Environmental Engineering, Universitat Politècnica de Catalunya BarcelonaTech, c/Jordi Girona 1-3, Building D1, E-08034 Barcelona, Spain

${ }^{2}$ Centre Internacional de Mètodes Numèrics en Enginyeria (CIMNE), Building Energy and Environment Group, Edifici GAIA (TR14), C/Rambla Sant Nebridi 22, E-08222, Terrassa, Barcelona, Spain

${ }^{3}$ Instituto Nacional de Eficiencia Energética y Energías Renovables (INER). 6 de Diciembre N33-32, Quito, Ecuador

${ }^{4}$ Green Empowerment, 140 SW Yamhill St, Portland, OR 97204, USA

* Corresponding author:

Tel.: +34 934016412

Fax: +34934017357

E-mail address: marianna.garfi@upc.edu 
Garfí, M., Marti-Herrero, J., Garwood A., Ferrer, I. Household anaerobic digesters for biogas production in Latin America: a review. Renewable \& Sustainable Energy Reviews, 60 (599-614) 


\begin{abstract}
This review aims to provide an overview of household biogas digester implementation in rural areas of Latin America. It considers the history of household digesters in Latin America, including technical, environmental, social and economic aspects. Several successful experiences have been promoted during the last decade, including the creation of the Network for Biodigesters in Latin America and the Caribbean (RedBioLAC) that provides a forum to coordinate implementation and research programs throughout the continent. Although the potential of this technology is well demonstrated, some barriers are identified, such as the need for technical improvements, lack of social acceptance and high investment costs. Thus, further efforts should be undertaken to overcome these barriers and improve the technical performance, social acceptance, economic benefits and environmental impact in order to enhance its widespread dissemination in energy poor communities.
\end{abstract}

\title{
Keywords
}

Anaerobic digestion; biomethanation; fertiliser; Latin America; renewable energy; rural communities; small-scale biodigesters 
Graphical abstract
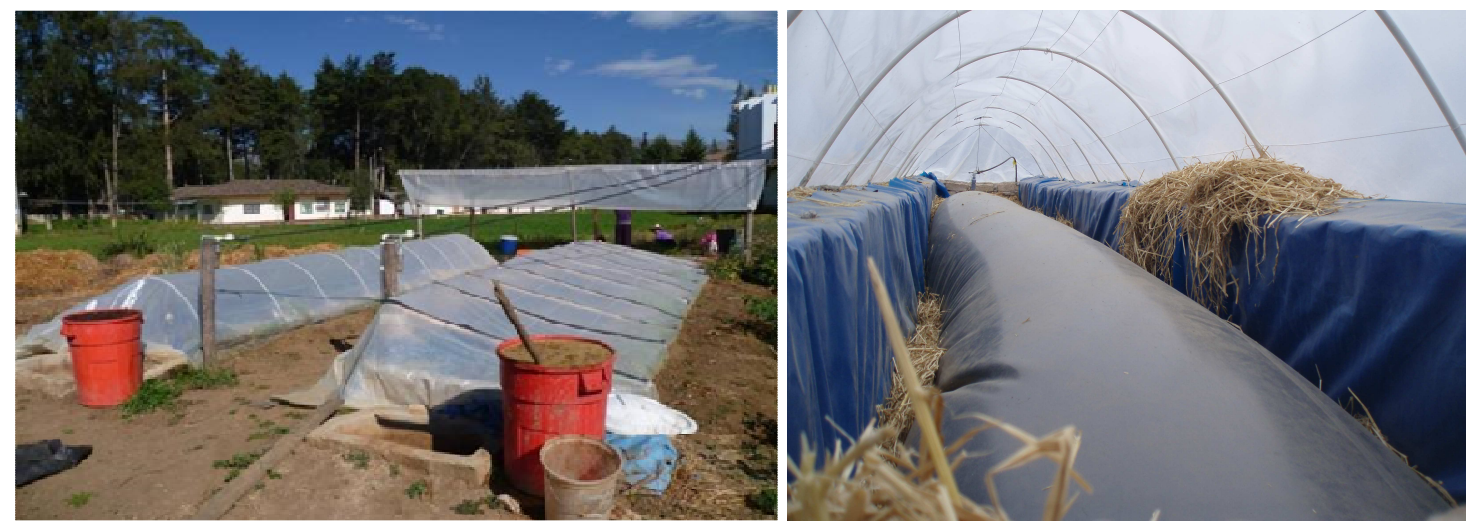


\section{Introduction}

Currently, 1.6 billion people in the world, mostly in rural areas, do not have access to electricity. Another 2.5 billion people still rely on traditional fuels, such as firewood and dried dung, to meet their daily heating and cooking needs. The use of traditional fuels is responsible for serious impacts on the environment and on people's health while limiting economic opportunity to overcome poverty [1]. Increasing access to modern and affordable energy is essential to improve basic services that require energy, such as water supply, sanitation, health care and education. Moreover, modern energy services contribute to poverty reduction by providing lighting, mechanical power, transport, and telecommunication services $[1,2]$. At the same time there is an urgent need to mitigate the climate change and reduce greenhouse gas (GHG) emissions, mainly generated by energy production and consumption $[3,4]$. Thus it is necessary to implement technologies that may contribute to both GHG emission reduction and poverty eradication.

Household digesters are considered a clean and environmentally friendly technology which can help rural communities to meet their energy needs for lighting, cooking and electricity, thus leading to improved living conditions $[5,6,7,8,9,10]$. Thanks to their technical, socio-economic and environmental benefits, household rural biogas plants have been spreading around the world since the 1970s [5,11]. However, the current situation of household digesters in developing nations differs from one to another.

The research and use of biogas has a long history in Asia. Since the 1970s, China and India were the two largest household biogas users in the world thanks to their extensive experience in anaerobic digestion, the availability of biomass and the strong support of national funds $[12,13]$. In these countries, several studies have shown and 
evaluated household digesters performance and biogas dissemination programmes [10, $13,14,15]$

In Latin America the implementation of household digesters was spurred after the energy crisis in the 1970s and several recent successful experiences have been reported $[7,16,17]$. Nevertheless, the number of biogas digesters installed in this region is far behind Asia, due to insufficient social acceptance, absence of long-term financial subsides, and lack of institutional support and follow up [7,17,18,19,20].

This review aims to provide an overview of household biogas digester implementation in rural areas of Latin America. It considers the history of household digesters in Latin America, including the technical, environmental, social and economic aspects. Most importantly, it examines the barriers to overcome in order to improve the technology and its dissemination.

\section{Household digester experiences in Latin America}

It is estimated that 31 million people in Latin America lack access to electricity (87\% in rural areas and $13 \%$ in urban areas) and that 85 million people rely on traditional biomass for cooking (70\% in rural areas and 30\% in urban areas) [2,21]. Access to basic modern energy is defined as the ability to satisfy basic energy needs (i.e. lighting, cooking, heating, education, healthcare and communication) through the use of reliable, efficient, affordable and environmentally friendly energy services [22].

Household digesters are simple and effective technologies available to deliver energy to poor communities, especially in remote rural areas. The first experiences of household digesters in Latin America date back to the end of the 1970s and beginning of the 1980s, when an interregional organization, the Latin American Energy Commission (OLADE), attempted to promote biogas in Bolivia, Guyana, Haiti, 
Honduras, Jamaica and Nicaragua. Ten digesters of various designs including batch, tubular and fixed dome were built in each country $[12,23,24]$. At the same time, the National University of Cajamarca (UNC) together with the Non-Governmental Organization (NGO) ITINTEC implemented almost 100 fixed dome digesters of 10-12 $\mathrm{m}^{3}$ in rural areas of the Peruvian Andes [25,26]. Likewise, the German Technical Cooperation (GTZ at that moment, now GIZ) supported the development and diffusion of the technology in the region. Most digesters were developed under a $100 \%$ subsidy model, but were not accompanied by specific training and follow up. For this reason, most of these experiences failed and household digesters were at some point abandoned by users. For instance, in the Bolivian Andes, the 65 fixed dome digesters installed from 1988 to 1992 were abandoned after a few years [17]. A survey carried out in 2007 showed that out of 100 fixed dome digesters installed at the Peruvian Andes during the 1980s, only one was still in operation [20].

At the end of the 1980s, the plastic tubular digester adapted from the PVC "red mud" model developed in Taiwan [27], was introduced in Colombia [28,29] by the Centre for Research on Sustainable Agricultural Production Systems (CIPAV). This model appeared to be easier to implement and less expensive than the fixed dome digester. Since then, tubular digesters have been spreading in rural areas of Latin American countries, especially Colombia, Costa Rica, Nicaragua, Ecuador, Honduras and Mexico [12,18,30,31]. Lately, this technology has been adapted to the harsh climate conditions of the Andean Plateau (2500-4500 m.a.s.1), in Bolivia (2003) [32] and Peru (2006) [33,34].

As a result of the renewed interest and efforts, the Network for Biodigesters in Latin America and the Caribbean (RedBioLAC) was created in 2009. RedBioLAC was formed and is administered by the NGO Green Empowerment, with support from the 
US Environmental Protection Agency and the Wuppertal Institute for Climate, Energy and Environment (WISIONS). The leadership board of RedBioLAC is comprised of representatives from NGOs, universities and businesses that promote digesters across Latin America. RedBioLAC's mission is to: (i) share information on innovations in the field; (ii) increase dialogue concerning biogas project promotion and management; (iii) identify and overcome technical, environmental, social and economic barriers for household, community and farm-scale digester dissemination in Latin America. This is achieved through an internet forum, an online library, webinars, international exchanges, coordinated research and annual conferences. So far, seven conferences have been carried out in different countries of Latin America (Peru 2009; Costa Rica 2010; Mexico 2011; Nicaragua 2012, Honduras 2013, Colombia 2014 and Chile 2015). Currently, it comprises 18 countries represented by 23 NGOs and Foundations, 15 Research and Development $(\mathrm{R}+\mathrm{D})$ centers and public institutions and 17 small companies, for a total of 55 organizations involved (RedBioLAC, 2014) (Figure 1). As a result, the coordination of household digesters research and implementation has been significantly improving over the last years. Furthermore, training is promoted by means of internships of students and professors among institutions [35].

\section{Please insert Figure 1}

Table 1 shows household digester dissemination projects in Latin America carried out by organizations involved in RedBioLAC. Most of these biogas programs were cofunded by NGOs, the private sector and biogas users. Beneficiaries were involved to increase their sense of responsibility towards their biogas plants and avoid digester abandonment. The most commonly used design is the plastic tubular digester and biogas 
is mainly used for cooking, while the digestate (also known as bio-slurry) is used as crop fertilizer. Management models have been focused on participation and training of users to avoid digester abandonment as occurred in the past.

\section{Please insert Table 1}

There is an increasing interest to develop National Biogas Programmes (NBPs) as those implemented in Asia and Africa [14]. Feasibility studies for NBP have been carried out in Honduras [36], Nicaragua [37], Bolivia [38] and Peru [39]. Since 2012, Nicaragua has been setting up a NBP with the goal of implementing 6,000 household digesters by 2017 [37]. Feasibility studies in Peru and Bolivia set goals of 10,000 and 6,000 digesters in five years, respectively [38,39]. The Bolivian NBP began in 2014 with the goal of installing 640 household digesters in 2.5 years.

\section{Anaerobic digesters designs in Latin America}

Household digesters design depends on climate conditions, available organic wastes, local materials and skills. Fixed dome, floating drum and tubular digesters are the most common models implemented in rural areas of developing countries. They were developed in Asia and have been adapted to the conditions of Latin America since the 1980s [12,20,30,32,34,40]. Design and operation parameters of household digesters implemented in Latin America are summarized in Table 2. There was no data available about floating drum digesters since there has been a limited usage in Latin America so $\operatorname{far}[18,20,41]$.

\section{Please insert Table 2}




\subsection{Fixed dome digesters}

The fixed dome digester developed in China is one of the most common models implemented in developing countries (Figure 2) [8,42]. It consists of a cylindrical chamber, a feedstock inlet and an outlet, which also serves as a compensation tank $[43,44]$. It is built completely underground of bricks and concrete. The system lacks proper mixing to avoid material sedimentation inside the digester and operates without heating. Biogas is accumulated in the upper part of the chamber. The level difference between the slurry inside the digester and the expansion chamber creates gas pressure. As biogas pressure builds-up, it pushes part of the substrate into the compensation tank $[8,44,45]$. A pipeline transports biogas from the digester to a reservoir, where it is stored and then used for cooking, heating or lighting.

\section{Please insert Figure 2}

The size of household digesters may vary depending on local conditions, biogas needs, organic waste and water availability. The volume of household digesters typically varies between $10 \mathrm{~m}^{3}$ and $20 \mathrm{~m}^{3}$ [20,46]. Community-scale digesters, built to produce biogas for 10-20 households, may have a volume of $50 \mathrm{~m}^{3}$ [46].

Fixed dome digesters require specialized labour for construction and relatively high investment costs [47]. Construction materials are not always available in rural and remote areas, but they generally are in nearby towns. However, transporting construction materials may not always be feasible [19]. A smaller fixed dome model (Camartec) was developed to minimize construction materials with respect to the traditional Chinese model, by reducing the size of the main chamber and making a 
second compensation chamber [48]. To date, the Camartec model has been mainly implemented in Africa [43]. Only in 2013 a pilot Camartec digester of $4 \mathrm{~m}^{3}$ was implemented at the Universidad Mayor de San Andrés (UMSA) in the Bolivian Andes.

Regarding operation and maintenance, the digester is fed semi-continuously (i.e., once a day) with organic waste (generally manure diluted with water). Removing the sludge is the only difficult maintenance task, which takes place no more than once a year. There is a manhole plug at the top of the digester to facilitate entrance for cleaning [23]. Digestate and sludge obtained after cleaning should be correctly disposed or reused in agriculture. The system should also be checked for biogas leakage in the digester or pipeline. Special maintenance is needed for cracks that could appear due to temperature fluctuation or earthquakes $[19,49]$. The lifespan of this system is around 20 years.

\subsection{Floating drum digester}

The floating drum (Hindu type) digester model, originally called Khadi and Village Industries Commission (KVIC), was developed in India during the 1960s (Figure 3). It consists of a cylindrical or dome shaped digester and a floating drum where the gas is held. It is built underground of concrete and steel. The digester does not include a mechanism for mixing or heating. The drum can be made of steel or PVC. The drum is placed on the digester and acts as a storage tank. The drum can move up and down depending on the amount of accumulated gas at the top of the reactor. The weight of the floating drum applies the pressure needed for gas flow through the pipeline $[8,50]$. Biogas is transported through the pipeline to a reservoir and used for cooking, heating and lightning. 


\section{Please insert Figure 3}

The volume of floating drum digesters implemented in Latin America ranges from $1.6 \mathrm{~m}^{3}$ to $10 \mathrm{~m}^{3}$. The larger ones $\left(6-10 \mathrm{~m}^{3}\right)$ were implemented to provide biogas to more than one household [20,41].

Floating drum digesters require skilled labour for installation. Investment costs are high due to expensive construction materials (concrete and steel) [6,51]. Construction materials are not always available in rural and remote areas for fixed dome digesters due to difficult transportation.

The system is fed daily with organic waste diluted with water. Other operation and maintenances tasks include digestate management, removing accumulated solids in the bottom of reactor, control of biogas leakage, and regularly painting the drum to avoid rust [8]. The lifespan of the system is generally shorter than that of the fixeddome digester (up to 15 years) because of drum corrosion [6].

\subsection{Tubular digesters}

The tubular digester, adapted from the PVC "red mud" model developed in Taiwan [27], consists of a tubular plastic bag, a PVC inlet and outlet, and a pipeline to collect biogas from the digester to the reservoir (Figure 4) [16,28,52]. The tubular polyethylene or PVC bag (the digester) is buried in a trench. Diluted feedstock flows through it from the inlet to the outlet. There is neither mixing to avoid material sedimentation inside the reactor nor heating to increase liquid temperature. A simple roof is generally used to protect the plastic bag. Biogas is accumulated in the upper part of the bag and collected by means of a gas pipeline connected to a reservoir, and then to the cookstove or other devices. The gas can be used for cooking, heating or lightning [40]. 


\section{Please insert Figure 4}

As mentioned above, the size depends on a number of factors including manure, water and land availability. In poor rural areas of Latin America, where the economy is based on subsistence agriculture and family farming, tubular digester volume is about 6$10 \mathrm{~m}^{3}[28,32,40]$. Bigger digesters (up to $70 \mathrm{~m}^{3}$ ) have been implemented in small-scale farms and university campuses of tropical regions [16,31].

During the last decade, a huge effort has been made to adapt the tubular digester to the harsh climate conditions of the Andean Plateau $[32,40]$. The daily temperature fluctuates between a minimum mean ranging from -15 to $3^{\circ} \mathrm{C}$, and a maximum mean ranging from 15 to $20^{\circ} \mathrm{C}$ [53], which adds barriers for the implementation of household digesters. Hence, in these areas, the tubular plastic bag is covered with a greenhouse, in an attempt to increase process temperature and reduce overnight heat losses. Indeed, in tubular digesters implemented in the Peruvian Andes, the temperature measured inside the digester greenhouse $\left(15-60^{\circ} \mathrm{C}\right)$ was always higher than ambient temperature $(10-$ $30{ }^{\circ} \mathrm{C}$ ), while the digester temperature remained fairly constant (around $20{ }^{\circ} \mathrm{C}$ ) [54]. In the Bolivian Plateau this design was proven to act as a solar heat collector with thermal inertia, and it maintained a constant temperature in the digester around $24-25^{\circ} \mathrm{C}$ [55]. Moreover, the passive solar gain might lead to a digester liquid temperature $8.5^{\circ} \mathrm{C}$ and $4{ }^{\circ} \mathrm{C}$ above the daily mean ambient and soil temperature, respectively [56]. Conversely, in digesters without passive heating, the digester liquid temperature tended to be equal to the soil temperature [57]. The effect of different greenhouse designs (shed, gable and dome roof) has also been compared. These greenhouse models were chosen according to local construction techniques and available materials [41]. In the dome roof 
greenhouse the temperature was slightly higher than in the shed roof greenhouse, however in both cases the digester liquid temperature remained fairly constant (around $\left.20{ }^{\circ} \mathrm{C}\right)[54,58]$. In addition, the dome roof had some practical advantages, as it eased maintenance tasks like weed removal and digester bag repair [58].

Design criteria for the digester, trench and greenhouse depend on each location. At high altitude (i.e. psychrophilic conditions) long HRT of 60-90 days are needed [40], whereas in tropical regions (i.e. mesophilic conditions) lower HRT (20-60 days) are used [28]. Recently, a new methodology for the design of tubular digesters has been proposed. It proposes optimum trench dimensions for typical circumferences of plastic bag $[59,60]$.

Tubular digesters are characterised by the ease of implementation and handling, since they do not require specialised skills for the construction and maintenance $[16,19,31,52]$. High quality pre-fabricated bags might not be locally available, however all construction materials can be easily transported [19], even by donkey [17]. As for the fixed dome and floating drum models, households should be trained to operate and manage the system [48]. The main necessary tasks are daily feeding, digestate management, removal of sludge in the bottom of reactor, and control of biogas leakage [17].

Plastic bags normally have a short lifespan, typically $<5$ years because of their susceptibility to mechanical damage $[19,43]$. However, PVC, polypropylene and high quality polyethylene bags are estimated to last between 8 to 10 years. Indeed, there are plastic digesters that have been operating for 10 years $[17,49]$.

\section{Technical aspects of biogas production}


Anaerobic digestion is a microbiological process that occurs naturally in the environment. In absence of oxygen organic matter is degraded and converted into methane by different bacterial communities through a series of metabolic stages: hydrolysis, acidogenesis and methanogenesis. In the first stage (hydrolysis), complex molecules (e.g. proteins, carbohydrates and lipids) are hydrolysed to soluble compounds (e.g. aminoacids, sugars, alcohols and long chain fatty acids) by hydrolytic bacteria using extracellular enzymes. In the second phase (acidogenesis), these compounds are transformed into short chain volatile fatty acids (e.g. propionic and butyric acid) and subsequently into acetic acid, hydrogen and carbon dioxide. Finally, during the last stage (methanogenesis), methanogenic bacteria convert acetic acid into methane and carbon dioxide [8,51]. Biogas composition depends on the substrate composition and operation parameters, being typically composed of $50-75 \% \mathrm{CH}_{4}, 25-50 \% \mathrm{CO}_{2}$ and 1$15 \%$ of other gases (e.g. water vapour, $\mathrm{H}_{2} \mathrm{~S}$, and $\mathrm{NH}_{3}$, among others) [51].

Anaerobic digestion performance depends on several parameters, including substrate composition (particularly the $\mathrm{C} / \mathrm{N}$ ratio), concentration of solids, mixing, temperature, hydraulic retention time (HRT), solids retention time (SRT) and organic loading rate (OLR) $[8,23]$. A balanced ratio between carbon sources and other nutrients such as nitrogen, phosphorus, and sulphur is most important for the substrate composition. Optimum $\mathrm{C} / \mathrm{N}$ ratio in the substrate is $15-45$. Higher $\mathrm{C} / \mathrm{N}$ ratio could decrease the reaction rate, while lower values may cause ammonium inhibition $[8,23]$. A neutral $\mathrm{pH}$ is favourable for biogas production, since most of the methanogens grow at the $\mathrm{pH}$ range of $6.7-7.5$. The concentration of total solids (\%TS) in the digester can vary from $2-15 \%$ (low solids anaerobic digestion) to $15-40 \%$ (high solids anaerobic digestion). In the former, larger digesters are needed to reach the same biogas production of the latter, due to the decreased organic matter-to-liquid ratio inside the 
digester. Mixing is also a key factor for biogas production. Too much mixing reduces performance, and without mixing foaming and solids sedimentation occurs [8]. Foam avoids biogas escape and collection, while inert solids sedimentation reduces the reactor lifespan. Moreover, without mixing contact between bacteria and substrate is reduced. Temperature ranges are classified according to optimum growth temperature of different methanogenic microorganisms, namely psychrophilic $\left(<25{ }^{\circ} \mathrm{C}\right)$, mesophilic $\left(30-40{ }^{\circ} \mathrm{C}\right)$ and thermophilic $\left(50-60{ }^{\circ} \mathrm{C}\right)$ [23]. In general, the higher the temperature, the faster the reaction rate and consequently, biogas production increases. Therefore, at higher temperatures lower volumes are required. HRT indicates the average period of time that the influent remains inside the digester. It should be at least 10-15 days and it varies depending on temperature from 10 to over 100 days [23]. SRT is the average period of time that solid particles are held inside the digester. In completely mixed reactors it is equal to the HRT, but in non-mixed reactors it is higher than HRT due to the sedimentation of solids. OLR is the amount of organic matter added per day. Increasing OLR results in higher solids concentration (\%TS). The optimal OLR depends on the substrate composition and digester model. The biogas production $\left(\mathrm{m}^{3}\right.$ biogas $\left.\mathrm{m}_{\text {digester }} \mathrm{d}^{-1}\right)$ divided by the OLR $\left(\mathrm{kg}_{\mathrm{VS}} \mathrm{m}^{-3}\right.$ digester $\left.\mathrm{d}^{-1}\right)$ results in the specific biogas production $\left(\mathrm{m}^{3}\right.$ biogas $\mathrm{kg}_{\mathrm{VS}}{ }^{-1}$ ), which is an indicator of the conversion efficiency of the substrate into biogas. Anaerobic digestion is a slow process and it takes several days for microorganisms to adapt to a new condition. Sudden temperature changes, organic or hydraulic overloading, presence of inhibitors such as ammonium or antibiotics, might cause inhibition [23]. Co-digestion, which is the simultaneous digestion of a mixture of two or more substrates, may increase biogas production by improving the nutrients balance ( $\mathrm{C} / \mathrm{N}$ ratio) and providing a feedstock with a more balanced composition, enhancing bacterial growth [8]. 


\section{Biogas production research in Latin America}

\subsection{Lab-scale research}

Table 3 summarizes literature results from lab-scale experiments which aimed at understanding the performance of anaerobic digestion in different conditions typical of rural areas of Latin America, i.e. using local feedstock under different temperature ranges (psychrophilic and mesophilic).

Comparing the effect of operational parameters on biogas production from manure, it was found that the most significant factor was temperature, followed by HRT, OLR and substrate characteristics, while there was no effect of pressure (i.e. altitude). Indeed, the anaerobic digestion of cow and llama manure under psychrophilic conditions $\left(11^{\circ} \mathrm{C}\right)$ reached a biogas production of $0.02-0.07 \mathrm{~m}_{\text {biogas }}^{3} \mathrm{~m}_{\text {digester }} \mathrm{d}^{-1}[61]$; while under mesophilic conditions $\left(25\right.$ and $\left.35^{\circ} \mathrm{C}\right)$ the biogas production increased to 0.10-0.34 $\mathrm{m}_{\text {biogas }}^{3} \mathrm{~m}_{\text {digester }}^{-1} \mathrm{~d}^{-1}$ for all tested substrates (i.e. cow, llama and sheep manure) $[61,62,63]$. Moreover, it was demonstrated that anaerobic digestion was sensitive to daily temperature fluctuation (from 20 to $35^{\circ} \mathrm{C}$ ). However, the process responded immediately to temperature increase, suggesting that methanogenic bacteria activity was well preserved during the period at low temperature [53]. This is relevant, since temperature cycles (i.e. day-night) may occur in unheated biogas production systems. As expected, increasing the HRT from 20 to 50 days had a positive effect on biogas production from cow and llama manure [61]. Also, increasing the OLR showed positive effects on biogas production, except for the highest OLR, demonstrating that optimal OLR for cow and llama manure was around 1-2 $\mathrm{kg}_{\mathrm{VS}} \mathrm{m}_{\text {digester }}^{-3} \mathrm{~d}^{-1}$ [61].

Feedstock composition had a strong influence on the specific biogas production (Table 3). The highest specific biogas production was obtained from cow and sheep 
manure (0.01 and $0.23 \mathrm{~m}^{3}$ biogas $\left.\mathrm{kg}_{\mathrm{Vs}}{ }^{-1}\right)$, while the lowest was observed from llama manure $\left(0.01-0.18 \mathrm{~m}_{\text {biogas }}^{3} \mathrm{~kg}_{\mathrm{Vs}}{ }^{-1}\right)[61,62,63]$. This was attributed to higher ammonium content in llama manure with respect to the others [61]. An improved anaerobic digestion performance was observed as a result of codigesting cow, llama and sheep manure, due to the fact that the relatively high nitrogen content of llama manure reduces cow nitrogen deficiency, balancing the $\mathrm{C} / \mathrm{N}$ ratio [63]. Quinoa stalk (Chenopodium quinoa Willd.) from agricultural crop residue, totora (Schoenoplectus tatora) and omacrophytes (aquatic flora) from Lake Titicaca (on the Bolivian Plateau), slaughterhouse and other fruit and vegetable waste were appropriate co-substrates to increase biogas production from llama, cow, swine and sheep manure $[62,64]$.

On the whole, lab-scale studies demonstrated that it is technically feasible to produce biogas from common manure in Latin America (i.e. cow, llama and sheep manure) under different temperature ranges (psychrophilic and mesophilic), and that codigestion of manure with other local organic waste improved anaerobic digestion performance. Consequently, interest increased to test full-scale household digesters under real operation conditions.

\section{Please insert Table 3}

\subsection{Pilot and full-scale research}

Table 4 shows biogas production and composition obtained in pilot and full-scale household digesters. Almost all experiments were designed to study tubular digester performance, which is the most common digester type used in Latin America. As mentioned above, these systems operate without heating; thus they worked at different temperature according to their location. In coastal and tropical regions digesters worked 
under mesophilic conditions $\left(>25^{\circ} \mathrm{C}\right)$, while at high altitude (e.g. Andean Plateau) liquid temperature was always around $20^{\circ} \mathrm{C}$ (psychrophilic conditions).

In coastal and tropical regions the biogas production in tubular digesters fed with cattle manure ranged between 0.12 and $0.39 \mathrm{~m}_{\text {biogas }}^{3} \mathrm{~m}_{\text {digester }} \mathrm{d}^{-1}[31,65,66,67]$; while at high altitude it ranged between 0.03 and $0.43 \mathrm{~m}_{\text {biogas }}^{3} \mathrm{~m}^{-3}$ digester $\mathrm{d}^{-1}[40,54,56,58,68,69]$. Although the harsh climate conditions (e.g. low temperature) constitute a limiting factor for biogas production at high altitude [53], household digesters provided clean fuel that covered around $60 \%$ of fuel needs for cooking [7]. In tropical regions, tubular digesters were shown to produce enough biogas to satisfy fuel needs for cooking and also for electricity generation $[16,31,65]$.

In some cases the biogas production was lower than expected from previous labscale experiments. It was mainly due to differing working conditions such as non-mixed vs. completely mixed reactors, HRT and OLR [54]. In non-mixed digesters there is less contact between bacteria and substrate, so biogas production may increase by $50 \%$ by introducing biofilm carriers (i.e. PET rings) that increase the surface area for substratebacteria contact [56]. As demonstrated in lab-scale experiments, longer HRT (39 vs. 14 days) resulted in higher biogas production (0.39 vs. $\left.0.12 \mathrm{~m}_{\text {biogas }}^{3} \mathrm{~m}_{\text {digester }} \mathrm{d}^{-1}\right)$ [31]. Even longer HRT of 60-90 days are commonly used at high altitude. However, using a HRT of 60 instead of 90 days and increasing the OLR to $1 \mathrm{~kg}_{\mathrm{Vs}} \mathrm{m}^{-3}$ digester $\mathrm{d}^{-1}$ may improve the biogas production, reducing tubular digesters volume and costs [40]. Even so, an OLR much higher than $1 \mathrm{~kg}_{\mathrm{Vs}} \mathrm{m}^{-3}$ digester $\mathrm{d}^{-1}$ and total solids concentration higher than $6-8 \%$ should be avoided in tubular digesters, since without mixing solids tend to settle out [31], reducing the useful volume and system lifespan [58].

The most frequently used feedstock in all full-scale experiments was cattle manure. The highest values of specific biogas production were obtained for cow manure 
at both psychrophilic and mesophilic conditions (between 0.17 and $0.44 \mathrm{~m}_{\text {biogas }}^{3} \mathrm{~kg}_{\mathrm{Vs}}{ }^{-1}$ ) $[31,40,54,56,68,69]$, while the specific biogas production of guinea pig manure was the lowest $\left(0.03-0.06 \mathrm{~m}_{\text {biogas }}^{3} \mathrm{~kg}_{\mathrm{vs}}{ }^{-1}\right)$ [54,58]. The low biogas production of guinea pig manure compared to cow manure was partly due to a composting pretreatment undertaken to obtain a homogeneous dilution for digester feeding [58]. In addition, the low production of biogas from guinea pig manure is due to the low digestibility and net energy content, which is greatly influenced by species, age and type of feeding [70]. Indeed, co-digestion of cow and guinea pig manure increased the specific biogas production with respect to guinea pig but not to cow manure [71], suggesting that codigestion with other local organic wastes should be explored.

In this sense, co-digestion of swine manure and cooking grease $(2.5 \%$ by volume) in tubular digesters increased the specific biogas production from the control (only swine manure) (from 0.38 to $0.42 \mathrm{~m}_{\text {biogas }}^{3} \mathrm{~kg}_{\mathrm{Vs}}{ }^{-1}$ ). However, increasing the grease concentration beyond $2.5 \%$ (by volume) resulted in a decrease of the methane content $[66,67]$ as a result of organic overloading and an unbalanced $\mathrm{C} / \mathrm{N}$ ratio which caused inhibition. Co-digestion of pig manure and urine was proved to be feasible [33,72]. The use of urine instead of water for pig manure dilution constitutes a key factor for household digester implementation in areas with water scarcity [33]. In recent years, the interest in digesters that use agro food waste such as coffee pulp has been increasing in Argentina, Bolivia, Colombia, Costa Rica, Guatemala, Mexico and Paraguay [41]. To date, there is still no data available about the performance of household digesters fed with these substrates.

Finally, in all research studies carried out in full-scale household tubular digesters the methane content in biogas was always above $40 \%$ and it increased with 
temperature from psychrophilic to mesophilic conditions (40-65\% and $60-70 \%$, respectively, Table 4).

\section{Please insert Table 4}

\section{Digestate reuse in Latin American agriculture}

In Latin America household digesters are implemented in rural communities where economy is based on subsistence and family farming. Family farming represents more than $80 \%$ of farming in Latin America and it is characterized by: (i) predominant use of family labor; (ii) limited access to resources such as land, technology and capital; (iii) low crop productivity, mainly for family subsistence [73,74]. Household digesters provide both biogas and digestate that is rich in nutrients (i.e. nitrogen, phosphorus, potassium, calcium, magnesium and sodium) and can be reused in agriculture as fertilizer to improve crop productivity. Through anaerobic digestion nutrients are transformed from an organic form (e.g. organic nitrogen from proteins) to a mineral form (e.g. $\mathrm{N}-\mathrm{NH}_{4}$ ), which is much more easily absorbed by plant roots $[67,75]$. Digestate is more homogeneous and can penetrate soil faster than manure. It also reduces weed seed germination and odours compared to dung. Consequently, digestate is considered more appropriate than manure, which is the most common fertilizer in rural communities of Latin America. Digestate can also replace chemical fertilizers, which are expensive and can cause long-term degradation of soil quality [76].

\subsection{Physical-chemical properties of digestate}

While the physical-chemical properties of digestate have been widely researched, there is little information about potential effects of digestate on crop 
fertilization. Digestate characteristics depend on feedstock composition and management, operating conditions and performance of the anaerobic digestion process. Table 5 summarizes the physical-chemical properties of the digestate from the most common feedstock in Latin America. The TS content in the digestate is always low (< $3 \% \mathrm{TS}$ ), as a consequence of solids sedimentation inside the reactor, typical of household digesters due to the lack of mixing [67,69,71]. Manure biodegradation is shown by the decrease in organic matter content (from 60-90\% VS/TS in the feedstock, to $40-65 \% \mathrm{VS} / \mathrm{TS}$ in the digestate). The concentration of nutrients (TKN, N-NH, $\mathrm{P}-$ $\mathrm{P}_{2} \mathrm{O}_{5}, \mathrm{~K}-\mathrm{K}_{2} \mathrm{O}$ ) in the digestate differs according to the feedstock composition and digesters operation. The hydrolysis of organic nitrogen is shown by the decrease in TKN concentration from the feedstock to the digestate and increase in $\mathrm{N}-\mathrm{NH}_{3}$ and $\mathrm{N}$ $\mathrm{NH}_{4}$ that are found in the biogas and digestate, respectively. In tubular digesters fed with guinea pig manure in the Peruvian Andes, the TKN concentration decreased by $72 \%$, while $\mathrm{N}-\mathrm{NH}_{4}$ concentration increased by $28 \%$. Thus, the $\mathrm{N}-\mathrm{NH}_{4} / \mathrm{TKN}$ ratio was higher in the digestate than in the feedstock (0.81 vs. 0.16) [71]. TKN was reduced by $35-45 \%$, while $\mathrm{NH}_{4}-\mathrm{N}$ increased by $80-90 \%$ in pilot and full-scale tubular digesters fed with swine and dairy manure in Costa Rica $[16,67]$. These results show how nutrient transformation was more efficient under mesophilic than psychrophilic conditions. The effect of temperature was also observed for faecal contamination indicators. Indeed, in tubular digesters the average total coliforms and E. coli concentration was reduced about two log-units under mesophilic conditions [67] and about one log-unit under psychrophilic conditions $[58,61]$.

\subsection{The performance of digestate as fertilizer}


Even if digestate reuse as fertilizer appears to be as important as biogas for rural families of Latin America [17], very few scientific studies have been carried out to assess the properties of digestate from household digesters for crop fertilization. The potential of digestate as an effective source of nutrients for duckweed in ponds was evaluated in Colombia. Results showed that biomass yield and protein in the duckweed dry matter were linearly correlated to the nitrogen concentration in the pond water, which increased by adding digestate [77]. Also in Colombia, an assay under farm conditions with maize assessed three additives with potential to improve soil fertility and health: (i) biochar, (ii) a culture of native microorganisms derived from fertile soils and (iii) digestate. Results suggested that the digestate increased the maize foliage growth by $70 \%$ and root weight by $100 \%[78]$.

In the Peruvian Andes a preliminary study was carried out in order to analyse the potential of the digestate as fertilizer for potato (Solanum tuberosum), the most common crop for family subsistence. Digestate from a tubular digester fed with guinea pig manure was compared with a control (without fertilizer). The results highlighted that using the effluent as fertilizer increased the potato yield per hectare by $100 \%$ (26 kg ha ${ }^{1}$ ) [58]. The positive effect of the digestate was confirmed with a more complex study that considered four treatments in a potato trial: control without fertilizer, digestate, manure pre-compost, and a mixture of digestate and manure pre-compost (50-50\% on a nitrogen basis). Compared to the control, the potato yield increased up to $27.5 \%$ with the digestate and $15.1 \%$ with manure pre-compost [71]. Similarly, a forage ( $L$. multiflorum and $T$. pratense L.) field trial, which is the most common crop in rural communities of Peruvian Andes for cattle feeding, compared the following treatments: control without fertilization, digestate at $50 \%$ dose, digestate at $100 \%$ dose and 
digestate at $150 \%$ dose. Compared to the control, the forage yield increased up to $8.8 \%$ with digestate at $100 \%$ dose and digestate at $150 \%$ dose [71].

Solids and nutrients concentrations in the digestate from tubular digesters are relatively low, due to feedstock dilution before feeding and solids retention inside the system. Consequently, fertilizing crops implies the use of large volumes of digestate to meet nitrogen crops needs [71]. Notwithstanding, digestate showed better performance compared with manure. Also, farmers reported the digestate capacity to protect crops from freezing and recover from damages caused by frost, after digestate foliar application [17]. Although anaerobic digestion can reduce microbial pathogen concentration, the digestate may not be completely safe especially at short HRT and under psychrophilic conditions $[51,71,79,80]$. To prevent health risks, digestate needs to be properly treated (e.g. by means of a sand filter) before application. Alternatively, the digestate should be applied before seedtime and avoided on leaf vegetable crops. Further studies should be carried out in order to evaluate the fertilizing potential of sludge accumulated inside the digester.

\section{Environmental aspects}

Anaerobic digesters may reduce pressure on the environment by [7,9,49]: (i) controlling environmental pollution by treating wastewater and organic wastes; (ii) reducing deforestation by providing a clean fuel to substitute firewood; (iii) reducing GHG emissions. Environmental benefits depend on biogas production and use, as well as construction materials. So far, few studies have been carried out to quantify the environmental impacts of household digesters in Latin America.

The global warming mitigation potential of biogas production from animal waste was estimated for developing countries, considering: (i) GHG emission reduction 
potential through manure management; (ii) emission mitigation potential due to traditional fuels (firewood and kerosene) substitution; (iii) emission mitigation potential of digestate through nitrogen, phosphorous and potassium fertilizer substitutions. Results suggested that 316 million tons $\mathrm{CO}_{2 \text { equ }}$ could be mitigated annually in Latin America through the use of available animal waste and human excreta for biogas production and subsequent utilization of the digestate as fertilizer [51].

An emergy analysis was performed to assess the relative sustainability and environmental impact of small-scale energy production using tubular digesters to treat livestock manure in Costa Rica [30]. Emergy is defined as the total amount of available energy (or exergy) of one kind that is used up directly or indirectly in a process. The results demonstrated that the production of biogas and the generation of electricity from tubular digesters in Costa Rica are environmentally sustainable processes. Nevertheless, sustainability is reduced when biogas is used to generate electricity, due to the high emergy value associated with the electricity generation equipment, machinery and energy loss.

The environmental assessment of household tubular digesters implemented in rural communities of the Peruvian Andes, where biogas is mainly used for cooking, quantified the $\mathrm{CO}_{2 \mathrm{eq}}$ emissions and firewood consumption reduction. $\mathrm{CO}_{2 \mathrm{eq}}$ emissions before the implementation of digesters were $5448.04 \mathrm{kgCO}_{2 \mathrm{eq}} \mathrm{year}^{-1}$ per family, due to firewood use for cooking and lack of manure management. Where digesters are used, $\mathrm{CO}_{2 \mathrm{eq}}$ emissions were about $50 \%$ lower $\left(2703.97 \mathrm{kgCO}_{2 \mathrm{eq}}\right.$ year $^{-1}$ per family) than in the previous scenario. Similarly, firewood consumption was reduced by 53\%. Although the potential benefits were restricted by the performance of biogas systems at high altitude (i.e. lower biogas production than in tropical regions) household digesters reduced GHG emission and deforestation appreciably (around 50\%) [7]. 
Furthermore, fixed dome and plastic tubular digester implemented in the Peruvian Andes were compared in terms of environmental impact, using the life cycle assessment (LCA) methodology. The results showed that the plastic tubular digester caused the highest impact as a result of the relatively short lifespan of plastic materials and geomembrane. In the fixed dome model, most environmental impact corresponded to concrete and bricks. Minimising the use of plastics and using construction materials with longer lifespans might improve the environmental performance of tubular digesters. Furthermore, more environmentally friendly materials, such as bioplastics, should be considered in the future [19].

In this context, household digester contribution to environmental protection could be increased by: (i) improving biogas production; (ii) choosing local and sustainable materials with longer lifespans; (iii) designing appropriate equipment for biogas use which reduce loss (e.g. machinery for electricity generation, biogas cookstove, and biogas lamps).

\section{Social aspects}

In addition to environmental benefits, household digesters may bring a number of social and health benefits. In Latin America $14 \%$ of the total primary energy demand relies on traditional biomass, mainly firewood for cooking [2]. Burning solid fuels without improved cookstoves produces smoke and soot particulate, which contribute to indoor air pollution. There is consistent evidence that exposure to indoor air pollution increases the risk of a number of acute respiratory infections [9,81]. Women and children suffer the most from indoor air pollution because they are traditionally responsible for cooking [81]. Replacing solid fuels with biogas improves indoor air quality, improving health and living quality [49,51]. A study carried out in the Peruvian 
Andes estimated that indoor emissions of soot particulate would decrease by $60 \%$ due to the reduction of time spent cooking with firewood [7].

Women and children are also primarily responsible for firewood collection, which is a time consuming and exhausting task. The time spent collecting solid fuel also imposes opportunity costs that constrain socio-economic development [7,51]. A survey carried out in rural communities of the Peruvian Andes, where biogas is mainly used for cooking, quantified that digester implementation reduced the time for firewood collection by $50 \%$. Families who participated in the survey declared that children and women could already spend more time on other activities. Women confirmed that they used most of the saved time on recreation activities, social and community work, income generating activities and reading. These activities have the potential to increase their education, civic engagement and contributions to community development [7].

Even though household digester implementation leads to health and social benefits, socio-cultural issues may pose barriers for the widespread diffusion of this technology. The evaluation of a biogas programme, which consisted of the implementation of more than one hundred fixed dome digesters in rural areas of Peruvian Andes during the 1980s, highlighted that the most significant barriers for the successful use of the technology were: (i) lack of social acceptance of biogas technology and (ii) lack of an appropriate management model after implementation. Both factors were related to limited information and training for users [20].

In 2010, the NGO Green Empowerment developed a survey to gather data on projects carried out by 5 grantees of a coordinated biogas program in 5 countries. While most of the families using digesters were satisfied with their performance, the study pointed out that in some places of Latin America the use of manure to cook was not well accepted and that it was socially unacceptable to cook certain dishes with biogas. 
For example, in Costa Rica biogas covered $50 \%$ of cooking needs of participant families, because firewood was still used for red beans and meat. The author suggested providing comprehensive training modules to cover relevant issues like benefits and safety of biogas, installation, operation, maintenance, fertilizer production and application [18].

Recently, the results and lessons learned after installing nearly 750 household digesters in Bolivian Andes highlighted that [17,69]: (i) complete and clear information about digesters should be given to users, showing weaknesses and failures in addition to benefits; (ii) involvement of local technicians was essential for system follow up; (iii) biogas plant implementation, operation and maintenance should be integrated with families way of life and farming; (iv) existing social structures should be respected; (v) in countries where governments subsidize liquefied petroleum gas (LPG) (e.g. Bolivia, Ecuador), farming families are more interested in digestate than biogas; (vi) users should pay for their biogas plant and subsidies should be restricted to making the technology accessible to the poorest users, since it has been observed that the higher the subsides the higher the failure rate.

\section{Economic aspects}

Household digesters provide both biogas and digestate that can be used as fertilizer. They can replace traditional fuels (such as firewood and propane) and chemical fertilizers or compost, which could be expensive for families living in rural areas of Latin America. Thus, economic benefits of household digesters are associated to fuel and fertilizer savings. In Costa Rica it was estimated that families saved around 400 dollars per year for propane thanks to biogas use [18]. In Mexico, families saved around 600 and 750 dollars per year for fuel (firewood which was purchased) and fertilizer, 
respectively [18]. In rural communities of the Peruvian Andes families saved around 50 dollars per year (about $1-2 \%$ of family annual income) by using digestate as fertilizer instead of compost [7].

As mentioned above, digestate can have a positive effect on crop production, resulting in an increase in crop yield. In the Peruvian Andes it was estimated that by selling the additional potato production, the family annual income could increase by 2 $3.4 \%$. This estimation was based on a preliminary study that showed that the digestate increased the potato yield per hectare by $100 \%$ as compared to control (without fertilizer) [7].

Despite economic benefits, costs and financing are significant barriers to the dissemination of digesters in rural areas of Latin America where economy is mainly based on subsistence and family farming. Household digester capital costs may vary depending on the design, materials availability, size and location. Capital costs of tubular digesters in Latin America range from 100 to 700 dollars. In some countries, such as Bolivia, Costa Rica and Nicaragua, low-density polyethylene was mainly used for the plastic bag, resulting in capital costs around 100-200 dollars (excluding labour). Costs increased up to 500-700 dollars when high quality polyethylene or pre-fabricated PVC and polypropylene geomembrane were chosen, as in Ecuador, Nicaragua, Mexico and Peru [18]. Pre-fabricated PVC or polypropylene bags are characterized by ease of implementation, robustness and durability, therefore their cost is much higher than polyethylene bags (around 300 vs. 70 dollars, respectively, for the bag alone) [19,82]. For tubular digesters adapted to the Andean Plateau, greenhouse implementation also increased the capital costs. It accounted for $15 \%$ of the total cost for household digesters implemented in the Peruvian Andes [19]. Initial investment costs for fixed dome and floating drum (Hindu-style) biogas plants in Latin America are about 700-1,200 dollars 
(excluding labour), depending on local materials (mainly bricks and cement) prices $[18,19]$.

In addition to materials, labour construction costs are estimated at 530 and 130 dollars for fixed dome and tubular digesters, respectively [19,39]. Fixed dome construction is more expensive than tubular digester because it requires specialised labour, skilled supervision and time-intensive construction. A comparison between fixed dome and tubular digesters total capital cost was undertaken in the Peruvian Andes [19]. The comparison considered a lifespan of 20 years for all materials, except for plastics, digester PVC geomembrane and greenhouse polyethylene, which were reduced to 5 years according to manufacturers' specifications and literature [43]. Digester capital cost was estimated at 1,963 dollars for the fixed dome model and 1,729 dollars for the plastic tubular model. It included labour costs for digester installation. Moreover, the capital cost of the tubular digester included 4 times the geomembrane and greenhouse polyethylene (over 20 years). Indeed, the initial investment cost would be 706 dollars (341 dollars for the digester geomembrane and greenhouse polyethylene, plus 365 dollars for the rest of materials), which represents $36 \%$ of the fixed dome digester investment cost. However, the tubular model would require an investment of another 341 dollars every 5 years [19]. Accordingly, the tubular digester might be more affordable for low-income families due to a lower initial investment as compared to the fixed dome and floating drum models.

However, implementing the Camartec model could reduce fixed dome digester costs. It was estimated that the capital cost of the Camartec model $\left(6 \mathrm{~m}^{3}\right)$ could be about $50 \%$ lower than the Chinese model in the Andean Plateau (1,000 dollars for Camartec, including labour) $[37,47]$. This is within the construction costs of tubular polyethylene digesters (1,100 dollars, including labour) implemented in the Bolivian Andes, 
assuming that the plastic greenhouse and digester are replaced three times over a lifespan of 20 years [17].

In Costa Rica it was estimated that the capital cost of a household tubular polyethylene digester would be recovered in 6 months by replacing chemical fertilizer, propane or LPG with digestate and biogas [49]. The capital cost for an electricity generation project $(21,000$ dollars, including costs for digester, generator building, electric equipment, and hydrogen sulfide absorption tower) in a small farm of EARTH University in Costa Rica would be recovered in 10 years through electricity savings and reduction in wastewater fines [31]. The payback period of tubular polyethylene digester was estimated around 2 years in Cuba for the use of biogas instead of LPG [65].

To date, in most Latin America countries digester implementation is neither affordable nor sustainable for subsistence rural households without any subsidies. Further research should be carried out to [7]: (i) reduce digester costs; (ii) generate employment by creating local cooperatives for biogas system installation and maintenance; (iii) assess how much families can pay for digester installation and maintenance according to their income; (iv) evaluate carbon emissions trading or other sustainable subsidy mechanism. A sustained digester program may require an innovative financing mechanism such as microcredit or financial subsides to support purchase and after-sale maintenance of digesters [18].

\section{Conclusions and recommendations}

The first experiences of household digester implementation in Latin America date back to the 1970s-1980s. However, only during the last decade have biogas programmes shown successful results, demonstrating the benefits of household digesters in rural 
areas of Latin America. Still, there are several barriers to overcome in order to improve the technology and its dissemination in rural communities.

First of all, digester design should be selected according to local conditions. Several factors should be considered, such as water and waste (feedstock) availability, biogas and fertilizer needs, climate conditions, local skills, material availability, transportation access, and the price point.

Research studies demonstrated the viability of producing biogas from common waste available in rural communities of Latin America and showed that biogas produced satisfied fuel needs for cooking and, in some cases, for electricity generation. Further studies should be carried out to finding ways to improve the temperature inside the digester and biogas production by co-digestion, especially at high altitudes. The full potential of digestate and sludge use as a crop fertilizer still needs to be studied for many crops. Post-treatment should also be taken into account to reduce health risk from pathogens.

Biogas production and its uses appear to be environmentally sustainable processes in rural communities of Latin America. Nevertheless, efforts should be made to identify local and more durable and sustainable materials in order to reduce environmental impacts, while keeping costs low. Even if the capital costs of digesters may be recovered in a short time by replacing expensive traditional fuels and fertilizer with digestate and biogas, high investment costs are the most significant barrier for widespread digester use in rural areas of Latin America.

From a social point of view, household digesters improve health and quality of life especially for women and children. On the other hand, lack of social acceptance of biogas technology and an appropriate management model after the implementation may lead to failures in biogas programmes. Therefore, training is considered essential to 
overcome social and cultural barriers. It should inform users about benefits, limitations and safety of biogas plants, and correct operation and maintenance to avoid technology abandonment. Expanded participation of users and local stakeholders, especially NGOs and the government, would help garner long-term support and ensure programs sustainability.

While digesters have not been as widely adopted in Latin America as they have been in Asia, recent research, program implementation and collaborative networks bring to light the challenges and potential for broader dissemination of this technology in the region.

\section{Acknowledgements}

The authors kindly acknowledge the support of the Centre for Development Cooperation, Universitat Politècnica de Catalunya. BarcelonaTech (Project CCD2010O031). Mariela Pino and organizations from RedBioLAC are kindly acknowledged for their contribution. The authors also appreciate WISIONS and the Environmental Protection Agency for supporting RedBioLAC. Marianna Garfí is grateful to Ministry of Economy and Competitiveness (Spain) (Plan Nacional de I+D+i 2008-2011, Subprograma Juan de la Cierva (JDC) 2012). Jaime Martí-Herrero is grateful to Hivos (Holland) and to the Prometeo Project of the Secretariat for Higher Education, Science, Technology and Innovation of the Republic of Ecuador. 


\section{References}

[1] United Nations Development Programme (UNDP). A Review of Energy in National MDG $\quad 2007 . \quad$ Reports. Available from: <http://www.undp.org/content/undp/en/home/librarypage/environmentenergy/sustainable_energy/a_review_of_energyinnationalmdgreports/> accessed 16.05.14]

[2] Sheinbaum-Pardo C, Ruiz BJ. Energy context in Latin America. Energy 2012;40: $39-46$

[3] International Energy Agency (IEA). $\mathrm{CO} 2$ emissions from fuel combustion e highlights. Paris: IEA; $2010 . \quad$ Available from: <http://www.iea.org/co2highlights/co2highlights.pdf; 2010> [last accessed 21.05.14]

[4] Intergovernmental Panel on Climate Change (IPPC). Climate change 2007: synthesis report. UNEP, WMO: 2007. Available from: http://www.ipcc.ch/pdf/assessment-report/ar4/syr/ar4_syr.pdf

[5] Bond T, Templeton MR. History and future of domestic biogas plants in the developing world. Energy for Sustain Dev 2011;15:347-354.

[6] Cheng S, Li Z, Mang HP, Huba EM, Gao R, Wang X. Development and application of prefabricated biogas digesters in developing countries. Renew Sustain Energy Reviews 2014;34:387-400

[7] Garfí M, Ferrer-Martí L, Velo E, Ferrer I. Evaluating benefits of low-cost household digesters for rural Andean communities. Renew Sustain Energy Reviews 2012;16:575-581.

[8] Rajendran K, Aslanzadeh S, Taherzadeh MJ. Household Biogas Digesters-A Review. Energies 2012;5:2911-2942. 
[9] Katuwal H, Bohara AK. Biogas: a promising renewable technology and its impact on rural households in Nepal. Renew Sustain Energy Reviews 2009;13:2668-2674.

[10] Van Groenendaal W, Gehua W. Microanalysis of the benefits of China's family size bio-digesters. Energy 2010;35:4457-66

[11] Feng Y, Guo Y, Yang G, Qin X, Song Z. Household biogas development in rural China: On policy support and other macro sustainable conditions. Renew Sustain Energy Reviews 2012;16:5617-5624

[12] Ni JQ, Naveau H, Nyns EG, Biogas: exploitation of a renewable energy in Latin America. Renew Energy 1993;3:763-779

[13] Chen L, Zhao L, Ren C, Wang F. The progress and prospects of rural biogas production in China. Energy Policy 2012;51:58-63

[14] Ghimire PC. SNV supported domestic biogas programmes in Asia and Africa. Renew Energy 2013;49:90- 94

[15] Lohan SK, Dixit J, Kumar R, Pandey Y, Khan J, Ishaq M, Modasir S, Kumar D. Biogas: A boon for sustainable energy development in India's cold climate. Renew Sustain Energy Reviews 2015;43:95-101

[16] Lansing S, Botero R, Martin J. Waste treatment and biogas quality in small-scale agricultural digesters. Bioresour Technol 2008;99:5881-5890.

[17] Martí-Herrero J, Chipana M, Cuevas C, Paco G, Serrano V, Zymla B, Heising K, Sologuren J, Gamarra A. Low cost tubular digesters as appropriate technology for widespread application: Results and lessons learned from Bolivia. Renew Energy 2014;(71):156-165.

[18] Garwood A. Network for Biodigesters in Latin America and the Caribbean: Case Studies and Future Recommendations. Technical notes No. IDB-TN-207; 2010. 
Available $\quad$ from: $\quad<$ http://www.iadb.org/en/publications/publication-

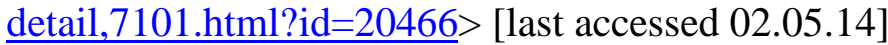

[19] Pérez I, Garfí M, Cadena E, Ferrer I. Technical, economic and environmental assessment of household biogas digesters for rural communities. Renew Energy $2014 ; 62: 313-31$

[20] Spagnoletta SA. Viability study for the application of small size biodigesters in the Andean rural zone of Cajamarca (Peru). 2007. Available from: <http://grecdh.upc.edu/docencia/treballs-dirigits/altres/spagnoletta-sebastiano-

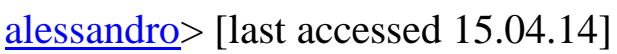

[21] IEA-UNDP- UNIDO. Energy poverty: how to make modern energy access universal. Paris, France: OECD/IEA; 2010

[22] Practical Action. Energy poverty: The hidden energy crisis. UK: 2008. Available from: <http://practicalaction.org/docs/advocacy/energy_poverty_hidden_crisis.pdf> [last accessed 20.06.14]

[23] Gunnerson CG, Stuckey DC. Integrated resource recovery: anaerobic digestionprinciples and practices for biogas systems World Bank Tech. Paper No. 49; UNDP Project Management Report No. 5; 1986

[24] Umana A. State of the art review of anaerobic processes in Latin America. Internal Report prepared for IRCWD; 1982

[25] Hilares S. El empleo de biodigestores en el Perú. Lima: ITINTEC Dirección de Tecnología; 1988

[26] Verástegui J, Mateo M, Lewis F. Generación de biogás en las Ares Rurales del Perú. ITINTEC Publication; 1980.

[27] Pound B, Bordas F, Preston TR. Characteristics of production and function of a 15 cubic metre red-mud PVC biogas digester. Tropical Anim Prod 1981;6:146-53. 
[28] Botero R, Preston TR. Biodigestor de bajo costo para la producción de combustible y fertilizante a partir de excretas. Manual para su instalación, operación y utilización. Cali: CIPAV; 1987

[29] Marchaim U, Biogas Processes for Sustainable Development. Rome; Bull FAO $\begin{array}{lllll}\text { Agric } & \text { Services: } & \text { 1992. } & \text { Available }\end{array}$ http://www.fao.org/docrep/t0541e/t0541e00.HTM > [last accessed 15.11.14]

[30] Ciotola RJ, Lansing S, Martin JF. Emergy analysis of biogas production and electricity generation from small-scale agricultural digesters. Ecol Eng 2011;37:1681- 1691 .

[31] Lansing S, Víquez J, Martínez H, Botero R, Martin J. Quantifying electricity generation and waste transformations in a low-cost, plug-flow anaerobic digestion system. Ecol Eng 2008b;34:332-348.

[32] Martí-Herrero J. Transfer of low-cost plastic biodigester technology at household level in Bolivia. Livest Res Rural Dev 2007;19(12). Available from: < http://www.lrrd.org/lrrd19/12/mart19192.htm> [last accessed 02.05.14]

[33] Ferrer I, Gamiz M, Almeida M, Ruiz A. Pilot project of biogas production from pig manure and urine mixture at ambient temperature in Ventanilla (Lima, Peru). Waste Manag 2009;29(1):168-173.

[34] Poggio D, Ferrer I, Batet L, Velo E. Adaptation of plastic tubular biodigesters to cold climates. Livest Res Rural Dev 2009;21(9). Available from: <http://www.lrrd.org//rrd21/9/pogg21152.htm > [last accessed 07.06.14]

[35] Ferrer-Martí, L., Garfí, M., Ferrer, I. Cooperation and human development projects as bachelor, master and phd thesis: evaluating an internship program. Procedia Social and Behavioral Sciences 2015;196: 63-68. 
[36] Bron, W., Sosa, B., van Nes, W., and Filomeno S. Estudio de la factibilidad para un programa de biogas en Honduras. Tegucigalpa: SNV \& Hivos; 2013. Available from <http://www.snvworld.org/es/publications/feasibility-study-honduras> [last accessed 02.09.14]

[37] Filomeno, S., Fernández, M., van Nes, W. Estudio de la factibilidad para un programa de biogas en Nicaragua. Managua: SNV \& Hivos; 2010. Available from < http://www.snvworld.org/en/publications/feasibility-study-nicaragua > [last accessed 20.09.14]

[38] Martí-Herrero J, Acosta-Bedoya F, Gonzales L. Plan del programa nacional de biodigestores de Bolivia. La Paz; Hivos: 2013. Available from: <http://www.snvworld.org/download/publications/snv-cimne-hivos_2013__plan_nacional_de_biodigestores_de_bolivia.pdf> [last accessed 02.06.14]

[39] Acosta-Bedoya F, Martí-Herrero J, Gonzales L, Oppenoorth H, Veen M, Valori M. Plan del Programa Nacional de Biodigestores en Perú. Lima: SNV and Hivos; 2013. Available $\quad$ from: $\quad<$ http://www.snvworld.org/en/regions/latinamerica/publications/plan-de-programa-nacional-de-biodigestores-en-peru $>$ [last accessed 30.06.14]

[40] Ferrer I, Garfí M, Uggetti E, Ferrer-Martí L, Calderón A, Velo E. Biogas production in low-cost household digesters at the Peruvian Andes. Biomass Bioenergy 2011:35;1668-1674.

[41] Network for Biodigesters in Latin America and the Caribbean (RedBioLAC). 2015. http://redbiolac.org/ [last update database 30.01.15]

[42] Shian ST, Chang MC, Ye YT, Chang W. The construction of simple biogas digesters in the province of Szechwan, China. Agricult Wastes, 1979;1(4):247-258. 
[43] Nzila C, Dewulf J, Spanjers H, Tuigong D, Kiriamiti H, van Langenhove H. Multi criteria sustainability assessment of biogas production in Kenya. Appl Energy 2012;93:496-506

[44] Sasse L, Kellner C, Kimaro A. Improved biogas unit for developing countries (Deutsche Gesellschaft für Technische Zusammenarbeit (GTZ)). Nairobi: GmbH, Vieweg \& Sohn Verlagsgesellschaft Braunschweig; 1991.

[45] Nazir, M, Biogas plants construction technology for rural areas. Bioresour Technol, $1991 ; 35: 283-289$.

[46] Gruber E, Herz H. The role of small-scale biogas production in rural areas for sustainable development in Germany and Peru. Energy for Sustain Dev 1996;3(4):58-63

[47] Veen M, Sanchiz JB, Acosta-Bedoya F, Ameller-Terrazas G. Estudio de Factibilidad para un Programa Nacional de biogas doméstico en Perú. 2009. Available from: <http://www.snvworld.org/sites/www.snvworld.org/files/publications/estudio_factibi $\underline{\text { lidad_programa_biodigestores_domesticos_peru_corregido_ok_20ago2012.pdf> }}$ [last accessed 16.04.14]

[48] Sasse L. Biogas plants. German Appropriate Technology Exchange (GATE) and German Agency for Technical Cooperation (GTZ) GmbH; 1988.

[49] Botero R. El biodigestor de bajo costo, su aporte a la mitigación del cambio climático y su potencial para reducir la pobreza rural en América latina y el Caribe. Colombia: Futura Tecnología Renovable y Sostenible 2011;1(11). Available from: <http://www.kelcolombia.com/futura-11.pdf $>$ [last accessed 30.05.14] 
[50] Singh KJ, Sooch SS. Comparative study of economics of different models of family size biogas plants for state of Punjab, India. Energy Convers Manag 2004;45:1329-1341.

[51] Surendra KC, Takara D, Hashimoto AG, Khanal SK. Biogas as a sustainable energy source for developing countries: Opportunities and challenges. Renew Sustain Energy Reviews 2014;31:846-859

[52] An BX, Preston TR. Gas production from pig manure fed at different loading rates to polyethylene tubular digesters. Livest Res Rural Dev 1999;11(1). Available from: < http://www.lrrd.org//rrd11/1/an111.htm $>$ [last accessed 02.06.14]

[53] Alvarez R, Lidén G. The effect of temperature variation on biomethanation at high altitude. Bioresour Technol 2008a;99:7278-7284.

[54] Garfí M, Ferrer-Martí L, Pérez I, Flotats X, Ferrer I. Codigestion of cow and guinea pig manure in low-cost tubular digesters at high altitude. Ecol Eng 2011;37, 2066-2070.

[55] Perrigault T, Weatherford V, Martí-Herrero J, Poggio D. Towards thermal design optimization of tubular digesters in cold climates: A heat transfer model. Bioresour Technol 2012;124:259-268.

[56] Martí-Herrero J, Alvarez R, Rojas MR, Aliaga L, Céspedes R, Carbonell J. Improvement through low cost biofilm carrier in anaerobic tubular digestion in cold climate regions. Bioresour Technol, 2014:(167):87-93

[57] Terradas-Ill G, Cuong H. Pham CH, Triolo JM, Martí-Herrero J, Sommer SG. Thermic Model to Predict Biogas Production in Unheated Fixed-Dome Digesters Buried in the Ground. Environl Sci Technol. 2014;48:3253-3262. 
[58] Garfí M, Ferrer-Martí L, Villegas V, Ferrer I. Psychrophilic anaerobic digestion of guinea pig manure in low-cost tubular digesters at high altitude. Bioresour Technol 2011;102, 6456-6359.

[59] Martí-Herrero J. Reduced hydraulic retention times in low-cost tubular digesters: Two issues. Biomass Bioenergy 2012;35:4481-4484.

[60] Martí-Herrero J, Cipriano J. Design methodology for low cost tubular digesters. Bioresour Technol 2012;108:21-27.

[61] Alvarez R, Villca S, Lidén G. Biogas production from llama and cow manure at high altitude. Biomass Bioenergy 2006;30:66-75.

[62] Alvarez R, Lidén G. Anaerobic codigestion of aquatic flora and quinoa with manures from Bolivian Altiplano. Waste Manag 2008b;28:1933-1940.

[63] Alvarez R, Lidén G. Low temperature anaerobic digestion of mixtures of llama, cow and sheep manure for improved methane production. Biomass Bioenergy 2009;33(3), 527-533.

[64] Alvarez R, Lidén G. Semi-continuous codigestion of solid slaughterhouse waste, manure, and fruit and vegetable waste. Renew Energy 2008c;33, 726-734.

[65] Chao R, Sosa R, Pérez AA, Cruz E. study on pig wastewater treatment with low cost biodigesters. Livest Res Rural Dev 2008;20(9). Available from:

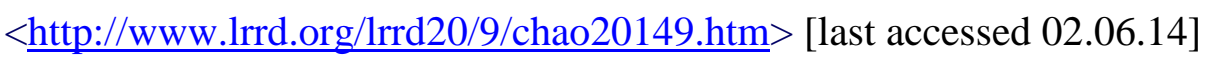

[66] Lansing S, Martin J, Botero R, Nogueira da Silva T, Dias da Silva E. Methane production in low-cost, unheated, plug-flow digesters treating swine manure and used cooking grease. Bioresour Technol 2010;101:4362-4370.

[67] Lansing S, Martin J, Botero R, Nogueira da Silva T, Dias da Silva, E. Wastewater transformations and fertilizer value when co-digesting differing ratios of swine 
manure and used cooking grease in low-cost digesters. Biomass Bioenergy 2010;34:1711-1720.

[68] Martí-Herrero J., Alvarez R., Cespedes, R., Rojas, M.R., Conde, V., Aliaga, L., Balboa, M., Danov, S. Cow, sheep and llama manure at psychrophilic anaerobic codigestion with low cost tubular digesters in cold climate and high altitude. Bioresour Technol, 2015;(118):238-246

[69] Martí-Herrero J, Ceron M, Garcia R, Pracejus L, Alvarez R, Cipriano X. Biogas The influence of users' behavior on biogas production from low cost tubular digesters: A technical and socio-cultural field analysis. Energy Sustain Dev 2015; (27):73-83

[70] Flachowsky G, Hennig A. Composition and digestibility of untreated and chemically treated animal excreta for ruminants - A review. Biologic Wastes 1990;31(1), 17-36.

[71] Garfí M, Gelman P, Comas J, Carrasco W, Ferrer I. Agricultural reuse of the digestate from low-cost tubular digesters in rural Andean communities. Waste Manag 2011;31:2584-2589.

[72] Pedraza G, Chará J, Conde N, Giraldo S, Giraldo L. Evaluación de los biodigestores en geomembrana (PVC) y plástico de invernadero en clima medio para el tratamiento de aguas residuales de origen porcino. Livest Res Rural Dev 2002;14(1). Available at: <http://www.lrrd.org/lrrd14/1/Pedr141.htm> [last accessed 15.06.14]

[73] Food and Agriculture Organization (FAO). Agricultura Familiar en América Latina y el Caribe: Recomendaciones de políticas. 2014. Available from: < http://www.fao.org/docrep/019/i3788s/i3788s.pdf $>$ [las accessed 03.10.14] 
[74] Food and Agriculture Organization (FAO) and Inter American Development Bank (BID). Políticas para la agricultura familiar en América Latina y el Caribe

- Resumen ejecutivo. 2007. FAO, Santiago, Chile. Available from: <http://www.fao.org/3/a-a1244s.pdf $>$ [las accessed 03.10.14]

[75] Massé DI, Croteau F, Masse L. The fate of crop nutrients during digestion of swine manure in psychrophilic anaerobic sequencing batch reactors. Bioresour Technol 2007;98(15):2819-2823.

[76] Sapp M, Harrison M, Hany U, Charlton A, Thwaites R. Comparing the effect of digestate and chemical fertiliser on soil bacteria. Appl Soil Ecology 2015;86:1-9

[77] Rodríguez L, Preston TR. Use of effluent from low-cost plastic biodigesters as fertilizer for duck weed ponds. Livest Res Rural Dev 1996; 8(2). Available from:

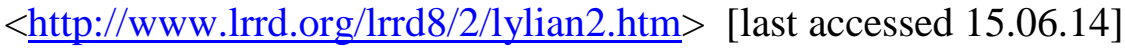

[78] Rodríguez L, Salazar P, Preston TR. Effect of a culture of "native" microorganisms, biochar and biodigester effluent on the growth of maize in acid soils. Livest Res Rural Dev 2011;23(10). Available from: <http://www.lrrd.org//rrd23/10/rodr23223.htm> [last accessed 15.06.14]

[79] Gadre RV, Ranade DR, Godbole SH. A note on survival of salmonellas during anaerobic digestion of cattle dung. J Appl Bacteriol 1986;60:93-6.

[80] Kearney TE, Larkin MJ, Frost JP, Levett PN. Survival of pathogenic bacteria during mesophilic anaerobic digestion of animal waste. J Appl Bacteriol $1993 ; 75: 215-9$.

[81] World Health Organization (WHO). Indoor health pollution, health and the burden of disease. 2007. Available from: $<\underline{\text { http://www.who.int/indoorair/publications/nationalburden/en/ }>} \quad$ [last accessed $3.05 .14]$ 
[82] Martí-Herrero J. Biodigestores Familiares. Guía de diseño y manual de instalación. La Paz: Cooperación Técnica Alemana - GTZ, ISBN 978-99954-0-339-3; 2008

[83] Kalia AK, Kanwar, SS. Long-term evaluation of a fixed dome Janata biogas plant in hilly conditions. Bioresour Technol 1998;65:61-63

[84] Kanwar SS, Gutpa RK, Guleri RL, Singh SP. Performance evaluation of a $1 \mathrm{~m}^{3}$ modified, fixed-dome Deenbandhu biogas plant under hilly conditions. Bioresour Technol 1994;50(3):239-241 
Table 1. Household digester dissemination programmes developed by RedBioLAC members.

\begin{tabular}{|c|c|c|c|c|c|c|c|c|}
\hline Country & $\begin{array}{l}\text { Biogas programme } \\
\text { promoter }\end{array}$ & Financing model & $\begin{array}{l}\text { Imple } \\
\text { mentat } \\
\text { ion } \\
\text { period }\end{array}$ & Beneficiaries & Digester model & $\begin{array}{l}\text { Biogas } \\
\text { use }\end{array}$ & Management Model & Reference \\
\hline Argentina & Proteger Foundation & $\begin{array}{l}25 \% \text { Proteger } \\
\text { Foundation } \\
40 \% \text { users } \\
35 \% \text { external subsidies }\end{array}$ & $\begin{array}{l}2004- \\
\text { On- } \\
\text { going }\end{array}$ & 4 households & Floating drum & $\begin{array}{l}\text { Cooking } \\
\text { and } \\
\text { heating }\end{array}$ & $\begin{array}{l}\text { Community-based } \\
\text { management }\end{array}$ & [41] \\
\hline Bolivia & $\begin{array}{l}\text { Deutsche } \\
\text { Gesellschaft für } \\
\text { Internationale } \\
\text { Zusammenarbeit } \\
\text { (GIZ), Energising } \\
\text { Development } \\
\text { (EnDev-Bolivia) } \\
\text { and Centro } \\
\text { Internacional de } \\
\text { Métodos Numéricos } \\
\text { en Ingeniería } \\
\text { (CIMNE) }\end{array}$ & $\begin{array}{l}80 \% \text { users } \\
20 \% \text { GIZ and EnDev- } \\
\text { Bolivia }\end{array}$ & $\begin{array}{l}2007- \\
2012\end{array}$ & $\begin{array}{l}740 \text { households } \\
2 \text { Schools } \\
5 \text { Community } \\
\text { centres }\end{array}$ & $\begin{array}{l}\text { Tubular polyethylene } \\
\text { adapted to the } \\
\text { Andean Plateau }\end{array}$ & Cooking & $\begin{array}{l}\text { Potential users request } \\
\text { support to GIZ; } \\
\text { Training workshops for } \\
\text { users and follow up }\end{array}$ & {$[17,18]$} \\
\hline Bolivia & $\begin{array}{l}\text { Promoción de la } \\
\text { Sustentabilidad y } \\
\text { Conocimientos } \\
\text { Compartidos } \\
\text { (PROSUCO) NGO }\end{array}$ & $\begin{array}{l}100 \% \text { subsidies } \\
\text { Man power provided } \\
\text { by users }\end{array}$ & $\begin{array}{l}2008- \\
\text { On- } \\
\text { going }\end{array}$ & 45 households & $\begin{array}{l}\text { Tubular polyethylene } \\
\text { adapted to the } \\
\text { Andean Plateau }\end{array}$ & Cooking & $\begin{array}{l}\text { Community-based } \\
\text { management; } \\
\text { Training workshops for } \\
\text { users }\end{array}$ & [41] \\
\hline Bolivia & $\begin{array}{l}\text { Humanistisch } \\
\text { Instituut voor } \\
\text { Ontwikkelingssamen } \\
\text { werking (Hivos) } \\
\text { and CIMNE }\end{array}$ & $100 \%$ users & $\begin{array}{l}2012- \\
2013\end{array}$ & $\begin{array}{l}10 \text { households } \\
9 \text { community } \\
\text { centers }\end{array}$ & $\begin{array}{l}\text { Tubular polyethylene } \\
\text { adapted to Andean } \\
\text { Plateau }\end{array}$ & Cooking & $\begin{array}{l}\text { Focus on research and } \\
\text { development; } \\
\text { Technical assistance for } \\
\text { design, dissemination and } \\
\text { implementation strategies }\end{array}$ & [41] \\
\hline Bolivia & $\begin{array}{l}\text { Humanistisch } \\
\text { Instituut voor } \\
\text { Ontwikkelingssamen } \\
\text { werking (Hivos) }\end{array}$ & $\begin{array}{l}33 \% \text { users } \\
67 \% \text { external subsidies }\end{array}$ & $\begin{array}{l}2014- \\
\text { On } \\
\text { going }\end{array}$ & 30 households & $\begin{array}{l}\text { Tubular polyethylene } \\
\text { adapted to Andean } \\
\text { Plateau }\end{array}$ & $\begin{array}{l}\text { Cooking } \\
\text { and } \\
\text { heating }\end{array}$ & National biogas program & [41] \\
\hline
\end{tabular}




\begin{tabular}{|c|c|c|c|c|c|c|c|c|}
\hline Colombia & $\begin{array}{l}\text { University of } \\
\text { Tropical Agriculture } \\
\text { Foundation and Red } \\
\text { Colombiana de } \\
\text { Energía de la } \\
\text { Biomasa } \\
\text { (RedBioCOL } \\
\text { network) }\end{array}$ & $\begin{array}{l}\text { Tubular polyethylene } \\
\text { digesters: } \\
70-100 \% \text { users } \\
0-30 \% \text { subsidies } \\
\text { Tubular PVC digesters: } \\
100 \% \text { users }\end{array}$ & $\begin{array}{l}\text { 1990- } \\
\text { On- } \\
\text { going }\end{array}$ & $<50$ households & $\begin{array}{l}\text { Tubular polyethylene } \\
\text { and PVC }\end{array}$ & Cooking & $\begin{array}{l}\text { Training workshops for } \\
\text { users }\end{array}$ & {$[41]$} \\
\hline Colombia & $\begin{array}{l}\text { Fundación Centro } \\
\text { para la Investigación } \\
\text { en Sistemas } \\
\text { Sostenibles de } \\
\text { Producción } \\
\text { Agropecuaria } \\
\text { (CIPAV Foundation) }\end{array}$ & $\begin{array}{l}0-100 \% \text { Users } \\
0-100 \% \text { subsidies }\end{array}$ & $\begin{array}{l}2007- \\
2014\end{array}$ & 60 households & $\begin{array}{l}\text { Tubular polyethylene } \\
\text { and PVC }\end{array}$ & Cooking & $\begin{array}{l}\text { Training workshops for } \\
\text { users; } \\
\text { Farmers involved }\end{array}$ & [41] \\
\hline Costa Rica & $\begin{array}{l}\text { Escuela de } \\
\text { Agricultura de la } \\
\text { Región Tropical } \\
\text { Húmeda (EARTH } \\
\text { University) }\end{array}$ & $\begin{array}{l}50 \% \text { EARTH } \\
\text { University } \\
25 \% \text { subsidies } \\
25 \% \text { users }\end{array}$ & $\begin{array}{l}\text { 1994- } \\
\text { On- } \\
\text { going }\end{array}$ & $\begin{array}{l}2500 \\
\text { households }\end{array}$ & $\begin{array}{l}\text { Tubular polyethylene } \\
\text { and PVC }\end{array}$ & $\begin{array}{l}\text { Cooking } \\
\text { and } \\
\text { heating }\end{array}$ & $\begin{array}{l}\text { Students and local farmers } \\
\text { involved; } \\
\text { Training workshops for } \\
\text { users }\end{array}$ & {$[18,41]$} \\
\hline Cuba & $\begin{array}{l}\text { Estación } \\
\text { Experimental Indio } \\
\text { Hatuey }\end{array}$ & $\begin{array}{l}0-100 \% \text { Users } \\
0-100 \% \text { subsidies }\end{array}$ & $\begin{array}{l}2007- \\
\text { On } \\
\text { going }\end{array}$ & $\begin{array}{l}79 \text { households } \\
\text { and community }\end{array}$ & $\begin{array}{l}\text { Tubular polyethylene, } \\
\text { floating drum and } \\
\text { fixed dome }\end{array}$ & $\begin{array}{l}\text { Cooking, } \\
\text { heating, } \\
\text { lightenin } \\
\text { g and } \\
\text { electricity }\end{array}$ & $\begin{array}{l}\text { Students and local farmers } \\
\text { involved; } \\
\text { Training workshops for } \\
\text { users }\end{array}$ & [41] \\
\hline Ecuador & $\begin{array}{l}\text { Asociación de } \\
\text { Campesinos } \\
\text { Agroecológicos de } \\
\text { Intag (ACAI) and } \\
\text { Coordinadora } \\
\text { Ecuatoriana de } \\
\text { Agroecología (CEA) }\end{array}$ & $\begin{array}{l}\text { 100\% subsidies } \\
\text { Man power provided } \\
\text { by users }\end{array}$ & $\begin{array}{l}2002- \\
\text { On } \\
\text { going }\end{array}$ & 80 households & Tubular polyethylene & Cooking & $\begin{array}{l}\text { Agro ecological farmers } \\
\text { involved; } \\
\text { Local technicians involved } \\
\text { in installation and follow up }\end{array}$ & [41] \\
\hline Ecuador & $\begin{array}{l}\text { Cooperative for } \\
\text { Assistance and Relief } \\
\text { Everywhere (CARE) } \\
\text { NGO and }\end{array}$ & $\begin{array}{l}80 \% \text { CARE and UTN } \\
20 \% \text { users }\end{array}$ & $\begin{array}{l}2009- \\
2010\end{array}$ & 20 households & $\begin{array}{l}\text { Floating drum and } \\
\text { Tubular polyethylene }\end{array}$ & Cooking & Municipalities involved & [41] \\
\hline
\end{tabular}




\begin{tabular}{|c|c|c|c|c|c|c|c|c|}
\hline & $\begin{array}{l}\text { Universidad Técnica } \\
\text { del Norte (UTN) }\end{array}$ & & & & & & & \\
\hline Guatemala & $\begin{array}{l}\text { Asociación Alterna } \\
\text { NGO }\end{array}$ & $\begin{array}{l}\text { 20-30\% users } \\
60-80 \% \text { subsidies } \\
0-10 \% \text { Asociación } \\
\text { Alterna NGO }\end{array}$ & $\begin{array}{l}2010- \\
\text { On- } \\
\text { going }\end{array}$ & 22 households & $\begin{array}{l}\text { Floating drum and } \\
\text { Tubular PVC }\end{array}$ & $\begin{array}{l}\text { Cooking } \\
\text { and } \\
\text { heating }\end{array}$ & Promoting micro-enterprise & [41] \\
\hline Honduras & $\begin{array}{l}\text { Zamorano University } \\
\text { and Centro Zamorano } \\
\text { de Energía Renovable } \\
\text { (CZER) }\end{array}$ & $\begin{array}{l}100 \% \text { subsidies } \\
\text { Man power provided } \\
\text { by users }\end{array}$ & $\begin{array}{l}2011- \\
2012\end{array}$ & 23 households & $\begin{array}{l}\text { Tubular PVC and } \\
\text { polyethylene }\end{array}$ & $\begin{array}{l}\text { Cooking } \\
\text { and } \\
\text { lighting }\end{array}$ & $\begin{array}{l}\text { Students and local farmers } \\
\text { involved; } \\
\text { Training workshops for } \\
\text { users }\end{array}$ & [41] \\
\hline Mexico & $\begin{array}{l}\text { Instituto } \\
\text { Internacional de } \\
\text { Recursos Renovables } \\
\text { (IRRI) and Sistema } \\
\text { Biobolsa company }\end{array}$ & $\begin{array}{l}0-100 \% \text { Users } \\
0-100 \% \text { subsidies }\end{array}$ & $\begin{array}{l}2007- \\
\text { On- } \\
\text { going }\end{array}$ & $\begin{array}{l}1050 \\
\text { households }\end{array}$ & $\begin{array}{l}\text { Tubular pre- } \\
\text { fabricated } \\
\text { polypropylene and } \\
\text { linear low-density } \\
\text { polyethylene } \\
\text { geomembrane }\end{array}$ & $\begin{array}{l}\text { Cooking } \\
\text { and } \\
\text { heating }\end{array}$ & $\begin{array}{l}\text { Training workshops for } \\
\text { users; } \\
\text { Developing microcredit } \\
\text { option }\end{array}$ & {$[18,41]$} \\
\hline Nicaragua & $\begin{array}{l}\text { Asociación Feníx } \\
\text { (ASOFENIX) NGO }\end{array}$ & $\begin{array}{l}80 \% \text { ASOFENIX } \\
20 \% \text { users }\end{array}$ & $\begin{array}{l}2008- \\
2010\end{array}$ & 10 households & $\begin{array}{l}\text { Tubular polyethylene } \\
\text { and pre-fabricated } \\
\text { polypropylene } \\
\text { geomembrane }\end{array}$ & Cooking & $\begin{array}{l}\text { Selection of beneficiaries } \\
\text { by means of a survey; } \\
\text { Training workshops for } \\
\text { users }\end{array}$ & {$[18,41]$} \\
\hline Nicaragua & $\begin{array}{l}\text { SNV Netherlands } \\
\text { Development } \\
\text { Organisation and } \\
\text { Humanistisch } \\
\text { Instituut voor } \\
\text { Ontwikkelingssamen } \\
\text { werking (Hivos) }\end{array}$ & $\begin{array}{l}33 \% \text { users } \\
67 \% \text { external subsidies }\end{array}$ & $\begin{array}{l}2012- \\
\text { On } \\
\text { going }\end{array}$ & 750 households & $\begin{array}{l}\text { Tubular pre- } \\
\text { fabricated } \\
\text { polypropylene } \\
\text { geomembrane and } \\
\text { fixed-dome } \\
\text { (Camartec) }\end{array}$ & Cooking & National biogas program & [41] \\
\hline Paraguay & $\begin{array}{l}\text { Universidad Nacional } \\
\text { de Asunción }\end{array}$ & $\begin{array}{l}70 \% \text { external subsidies } \\
20 \% \text { Universidad } \\
\text { Nacional de Asunción } \\
10 \% \text { users }\end{array}$ & $\begin{array}{l}2011- \\
\text { On- } \\
\text { going }\end{array}$ & 18 households & Tubular polyethylene & $\begin{array}{l}\text { Cooking } \\
\text { and } \\
\text { heating }\end{array}$ & $\begin{array}{l}\text { Training workshops for } \\
\text { users }\end{array}$ & [41] \\
\hline Peru & $\begin{array}{l}\text { Instituto de } \\
\text { Investigación y } \\
\text { Desarrollo para el Sur }\end{array}$ & $100 \%$ users & $\begin{array}{l}\text { 2004- } \\
\text { On- } \\
\text { going }\end{array}$ & $\begin{array}{l}46 \text { households } \\
\text { and community }\end{array}$ & $\begin{array}{l}\text { Tubular pre- } \\
\text { fabricated PVC } \\
\text { geomembrane }\end{array}$ & $\begin{array}{l}\text { Cooking } \\
\text { and } \\
\text { heating }\end{array}$ & $\begin{array}{l}\text { Training workshops for } \\
\text { users }\end{array}$ & [41] \\
\hline
\end{tabular}




\begin{tabular}{|c|c|c|c|c|c|c|c|c|}
\hline Peru & Diaconia NGO & $\begin{array}{l}\text { 100\% Diaconia NGO } \\
\text { and external subsidies }\end{array}$ & $\begin{array}{l}2013- \\
2014\end{array}$ & 80 households & $\begin{array}{l}\text { Tubular polyethylene } \\
\text { an PVC }\end{array}$ & Cooking & Municipalities involved & {$[41]$} \\
\hline Peru & $\begin{array}{l}\text { Practical Actions - } \\
\text { ITDG NGO }\end{array}$ & $\begin{array}{l}90 \% \text { ITDG } \\
10 \% \text { Users }\end{array}$ & $\begin{array}{l}2007- \\
2010\end{array}$ & 25 households & $\begin{array}{l}\text { Tubular polyethylene } \\
\text { and pre-fabricated } \\
\text { PVC geomembrane } \\
\text { adapted to Andean } \\
\text { Plateau }\end{array}$ & $\begin{array}{l}\text { Cooking } \\
\text { and } \\
\text { lightning }\end{array}$ & $\begin{array}{l}\text { Selection of beneficiaries } \\
\text { by means of a survey; } \\
\text { Training workshops for } \\
\text { users }\end{array}$ & {$[18]$} \\
\hline
\end{tabular}

[17] Martí-Herrero et al., 2014; [18] Garwood, 2010; [41] RedBioLAC database (last update January 2015); 
Table 2. Design and operation parameters of household and small-scale digesters implemented in Latin America.

\begin{tabular}{|l|l|l|}
\hline & \multicolumn{1}{|c|}{ Fixed dome } & \multicolumn{1}{c|}{ Tubular digester } \\
\hline Digester design, material & Fixed dome, bricks and concrete & Tubular, PVC or polyethylene \\
\hline Covering & - & $\begin{array}{l}\text { Simple roof }(\mathrm{T})[28] \\
\text { Shed, Gable and dome } \\
\text { greenhouse }(\mathrm{H})[32,40,58]\end{array}$ \\
\hline Temperature range $\left({ }^{\circ} \mathrm{C}\right)$ & \multicolumn{2}{|c|}{$\begin{array}{l}\text { Psychrophilic }\left(<25^{\circ} \mathrm{C}\right)(\mathrm{H}) \\
\text { Mesophilic }(25-40 \circ \mathrm{C})(\mathrm{T})\end{array}$} \\
\hline Total volume $\left(\mathrm{m}^{3}\right)$ & \multicolumn{2}{|c|}{$\begin{array}{l}6-70(\mathrm{~T})[16,28] \\
6-10(\mathrm{H})[32,40]\end{array}$} \\
\hline Hydraulic residence time $(\mathrm{d})$ & $55[83,84]$ & $\begin{array}{l}20-50(\mathrm{~T})[16,28] \\
60-125(\mathrm{H})[40,56,58,69]\end{array}$ \\
\hline Substrate (dilution) & Cattle manure (1:1) [83] & $\begin{array}{l}\text { Cattle manure }(1: 5)(\mathrm{T})[28] \\
\text { Cattle manure }(1: 3)(\mathrm{H})[54,69]\end{array}$ \\
\hline Substrate dry weight $(\% \mathrm{TS})$ & $9-20[83,84]$ & $\begin{array}{l}3(\mathrm{~T})[28] \\
6-8(\mathrm{H})[54,69]\end{array}$ \\
& &
\end{tabular}

[16] Lansing et al., 2008; [20] Spagnoletta, 2007; [28] Botero and Preston, 1987; [32] Martí-Herrero, 2007; [40] Ferrer et al., 2011; [46] Gruber and Herz, 1996; [54] Garfí et al., 2011b; [56] Martí-Herrero et al., 2014b; [58] Garfí et al., 2011a; [69] Martí-Herrero et al., 2015b; [83] Kalia and Kanwar, 1998; [84] Kanwar et al., 1994. (T) Coastal and tropical regions; (H) High altitude (Andean Plateau) 
Table 3. Performance of household anaerobic digesters in Latin America: lab-scale research outcome.

\begin{tabular}{|c|c|c|c|c|c|c|c|c|c|c|}
\hline Reference & $\begin{array}{l}\text { Location } \\
\text { and } \\
\text { altitude } \\
(\mathrm{m} . \text { a.s.l) }\end{array}$ & $\begin{array}{l}\text { Digester } \\
\text { design }\end{array}$ & \begin{tabular}{|l|} 
Liquor \\
Temperature \\
$\left({ }^{\circ} \mathrm{C}\right)$
\end{tabular} & $\begin{array}{l}\text { Useful } \\
\text { Volume } \\
\left(\mathbf{m}^{3}\right)\end{array}$ & $\begin{array}{l}\text { HRT } \\
\text { (d) }\end{array}$ & Substrate & 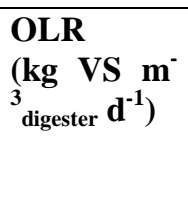 & $\begin{array}{l}\text { Biogas } \\
\text { production rate } \\
\left(\mathbf{m}_{\text {biogas }}^{3} \mathbf{m}^{-}\right. \\
\left.{ }_{\text {digester }} \mathbf{d}^{-1}\right)\end{array}$ & \begin{tabular}{|l|} 
Specific \\
Biogas \\
production \\
$\left(\mathbf{m}^{3}{ }_{\text {biogas }}\right.$ \\
kg $\left.^{-1}{ }^{-1}\right)$ \\
\end{tabular} & $\begin{array}{l}\text { Methane } \\
\left(\% \mathrm{CH}_{4}\right)\end{array}$ \\
\hline \multirow[t]{4}{*}{ [61] } & \begin{tabular}{|l|} 
Bolivia \\
3,800
\end{tabular} & CSTR & 11 & $2 \times 10^{-3}$ & $20-50$ & Cow manure & $0.52-3.22$ & $0.03-0.07$ & $0.01-0.06$ & $39-56$ \\
\hline & & & 35 & & & & & $0.10-0.31$ & $0.10-0.19$ & \begin{tabular}{|l|}
$46-61$ \\
\end{tabular} \\
\hline & & & 11 & & & Llama manure & $0.89-4.43$ & $0.02-0.06$ & $0.01-0.03$ & $21-57$ \\
\hline & & & 35 & & & & & $0.12-0.34$ & $0.06-0.18$ & $42-57$ \\
\hline \multirow[t]{6}{*}{ [53] } & \begin{tabular}{|l|} 
Bolivia \\
3,800 \\
\end{tabular} & CSTR & $11-25$ & $9.3 \times 10^{-3}$ & 30 & $\begin{array}{l}\text { Llama, cow and sheep manure } \\
\text { (33.3\% of each on a VS basis) }\end{array}$ & 2 & 0.24 & 0.12 & 56 \\
\hline & & & 15-29 & & & & & 0.29 & 0.15 & 55 \\
\hline & & & $19-32$ & & & & & 0.31 & 0.16 & 56 \\
\hline & & & 18 & & & & & 0.16 & 0.08 & 61 \\
\hline & & & 25 & & & & & 0.32 & 0.16 & 56 \\
\hline & & & 35 & & & & & 0.45 & 0.23 & 49 \\
\hline \multirow[t]{5}{*}{ [62] } & $\begin{array}{l}\text { Bolivia } \\
3,800\end{array}$ & CSTR & 25 & $1.8 \times 10^{-3}$ & 30 & Llama manure & 1.8 & 0.23 & 0.13 & 53 \\
\hline & & & & & & Cow manure & & 0.32 & 0.18 & 54 \\
\hline & & & & & & Sheep manure & & 0.32 & 0.18 & 53 \\
\hline & & & & & & $\begin{array}{l}\text { Quinoa stalk (Chenopodium } \\
\text { quinoa Willd.) }\end{array}$ & & 0.30 & 0.17 & 49 \\
\hline & & & & & & Totora (Schoenoplectus tatora) & & 0.10 & 0.06 & 27 \\
\hline
\end{tabular}




\begin{tabular}{|c|c|c|c|c|c|c|c|c|c|c|}
\hline & & & & & & o-Macrophytes (aquatic flora) & & 0.47 & 0.26 & 55 \\
\hline & & & & & & $\begin{array}{l}\text { Co-digestion of llama, cow } \\
\text { and sheep manure, quinoa, } \\
\text { totora and o-macrophytes } \\
\text { (different proportions from } 8 \\
\text { to } 58 \% \text { of each on VS basis) } \\
\end{array}$ & & $0.33-0.70$ & $0.18-0.39$ & $46-54$ \\
\hline \multirow[t]{5}{*}[64]{} & $\begin{array}{l}\text { Bolivia } \\
3,800\end{array}$ & CSTR & 35 & $1.8 \times 10^{-3}$ & $10-70$ & $\begin{array}{l}\text { Co-digestion of manure (cow } \\
\text { manure } 71 \% \text { by weight and } \\
\text { swine manure } 29 \% \text { by weight), } \\
\text { fruit and vegetables waste and } \\
\text { cattle and swine } \\
\text { slaughterhouse waste }(33.3 \% \\
\text { of each on a VS basis) } \\
\end{array}$ & $0.14-3.80$ & $0.03-1.01$ & $0.24-0.62$ & $44-59$ \\
\hline & & & & & 30 & $\begin{array}{l}\text { Manure (cow manure } 71 \% \text { by } \\
\text { weight and swine manure } 29 \% \\
\text { by weight) }\end{array}$ & 1.31 & 0.45 & 0.34 & 56 \\
\hline & & & & & & Fruit and vegetables waste & & 0.18 & 0.13 & 2 \\
\hline & & & & & & Slaughterhouse waste & & 0.17 & 0.13 & 45 \\
\hline & & & & & & $\begin{array}{l}\text { Co-digestion of manure (cow } \\
\text { manure } 71 \% \text { by weight and } \\
\text { swine manure } 29 \% \text { by weight), } \\
\text { fruit and vegetables waste and } \\
\text { cattle and swine } \\
\text { slaughterhouse waste } \\
\text { (different proportions from } 17 \\
\text { to } 67 \% \text { of each on a VS basis) } \\
\end{array}$ & & $0.22-0.89$ & $0.17-0.68$ & $25-57$ \\
\hline \multirow[t]{3}{*}[63]{} & $\begin{array}{l}\text { Bolivia } \\
3,800\end{array}$ & CSTR & 18 & $1.8 \times 10^{-3}$ & $10-30$ & $\begin{array}{l}\text { Co-digestion of llama, sheep } \\
\text { and cow manure (33.3\% of } \\
\text { each on a VS basis) }\end{array}$ & $0.50-8.10$ & $0.03-0.23$ & $0.02-0.09$ & $42-58$ \\
\hline & & & 25 & & & & & $0.07-0.48$ & $0.04-0.15$ & $39-54$ \\
\hline & & & 25 & & 50 & Cow manure & 1.2 & 0.21 & 0.17 & 55 \\
\hline
\end{tabular}




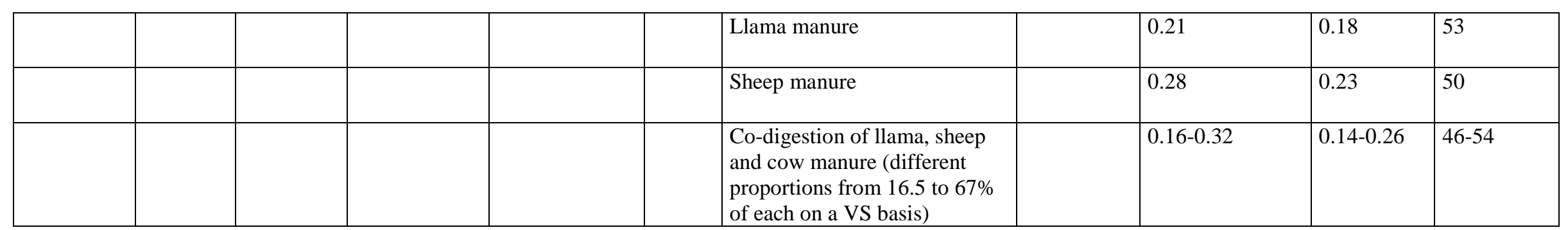

[61] Alvarez et al., 2006; [53] Alvarez and Lidén, 2008: [62] Alvarez and Lidén, 2008; [64] Alvarez and Lidén, 2008; [63] Alvarez and Lidén, 2009. CSTR: continuous

stirred tank reactor; HRT: hydraulic residence time; OLR: organic loading rate. Biogas volumes expressed at $0^{\circ} \mathrm{C}$ and $1 \mathrm{~atm}$ 
Table 4. Performance of household and small-scale digesters in Latin America: pilot and full-scale research outcome.

\begin{tabular}{|c|c|c|c|c|c|c|c|c|c|c|}
\hline Reference & $\begin{array}{l}\text { Location } \\
\text { and } \\
\text { altitude } \\
\text { (m.a.s.l) }\end{array}$ & $\begin{array}{l}\text { Digester } \\
\text { design }\end{array}$ & \begin{tabular}{|l|} 
Liquor \\
Temperature \\
range \\
$\left({ }^{\circ} \mathrm{C}\right)$
\end{tabular} & \begin{tabular}{|l|} 
Useful \\
Volume \\
$\left(\mathrm{m}^{3}\right)$
\end{tabular} & $\begin{array}{l}\text { HRT } \\
\text { (d) }\end{array}$ & Substrate & $\begin{array}{|lr|}\text { OLR } & \\
\left(\mathbf{k g}_{\mathbf{v S}}\right. & \mathbf{m}^{-} \\
3 & \left.\mathbf{d i g e s t e r}^{-1}\right) \\
\end{array}$ & $\begin{array}{l}\text { Biogas } \\
\text { production } \\
\text { rate } \\
\left(\mathbf{m}_{\text {biogas }}^{\mathbf{3}} \mathbf{m}^{-}\right. \\
\left.\mathbf{3}_{\text {digester }} \mathbf{d}^{-1}\right) \\
\end{array}$ & \begin{tabular}{|l|} 
Specific \\
Biogas \\
production \\
$\left(\mathbf{m}_{\text {biogas }}^{3} \mathrm{~kg}_{\mathrm{vs}}{ }^{-1}\right)$
\end{tabular} & $\begin{array}{l}\text { Methane } \\
\left(\% \mathrm{CH}_{4}\right)\end{array}$ \\
\hline \multicolumn{11}{|c|}{ Coastal and tropical regions } \\
\hline \multirow[t]{2}{*}[33]{} & \multirow{2}{*}{$\begin{array}{l}\text { Peru } \\
0-100\end{array}$} & \multirow[t]{2}{*}{ Batch reactor } & \multirow[t]{2}{*}{$22-33$} & 0.13 & - & Pig manure and water & - & $0.04^{\mathrm{x} \text { and } \mathrm{z}}$ & $0.06^{\mathrm{x} \text { and } \mathrm{z}}$ & 22 \\
\hline & & & & 0.15 & - & $\begin{array}{l}\text { Co-digestion of pig } \\
\text { manure and urine }\end{array}$ & - & $0.05^{\mathrm{x} \text { and } \mathrm{z}}$ & $0.07^{x \text { and } z}$ & 49 \\
\hline$[65]$ & $\begin{array}{l}\text { Cuba } \\
0-50\end{array}$ & $\begin{array}{l}\text { Tubular } \\
\text { polyethylene }\end{array}$ & $24-25$ & 12.3 & 15.9 & Pig manure & 1.17 & $\begin{array}{l}0.28^{\mathrm{x}} \\
0.25^{\mathrm{y}}\end{array}$ & $\begin{array}{l}0.24^{\mathrm{x}} \\
0.21^{\mathrm{y}}\end{array}$ & - \\
\hline$[16]$ & $\begin{array}{l}\text { Costa } \\
\text { Rica } \\
50-350\end{array}$ & $\begin{array}{l}\text { Tubular } \\
\text { polyethylene }\end{array}$ & $25-27$ & $\begin{array}{l}20-56^{* *} \\
(7)^{*}\end{array}$ & $11-91$ & Swine and dairy manure & - & - & - & $61.40-72.50$ \\
\hline \multirow[t]{2}{*}[31]{} & \multirow{2}{*}{$\begin{array}{l}\text { Costa } \\
\text { Rica } \\
50\end{array}$} & \multirow[t]{2}{*}{$\begin{array}{l}\text { Tubular } \\
\text { polyethylene }\end{array}$} & \multirow[t]{2}{*}{$25-27$} & $68^{* * *}$ & 39 & Dairy manure & 1.01 & $\begin{array}{l}0.40^{\mathrm{x}} \\
0.39^{\mathrm{y}}\end{array}$ & $\begin{array}{l}0.40^{\mathrm{x}} \\
0.38^{\mathrm{y}}\end{array}$ & 62.60 \\
\hline & & & & $49^{* * *}$ & 14 & Swine manure & 1.28 & $0.12^{x \text { and } y}$ & $0.10^{\mathrm{x} \text { and } \mathrm{y}}$ & 76.40 \\
\hline \multirow[t]{4}{*}{\begin{tabular}{|l}
$66,67]$ \\
\end{tabular}} & \multirow{4}{*}{$\begin{array}{l}\text { Costa } \\
\text { Rica } \\
50\end{array}$} & \multirow[t]{4}{*}{$\begin{array}{l}\text { Tubular } \\
\text { polyethylene }\end{array}$} & \multirow[t]{4}{*}{$22-26$} & \multirow[t]{4}{*}{0.2} & \multirow[t]{4}{*}{40} & Swine manure & 0.34 & $\begin{array}{l}0.14^{\mathrm{x}} \\
0.13^{\mathrm{y}}\end{array}$ & $\begin{array}{l}0.42^{\mathrm{x}} \\
0.38^{\mathrm{y}}\end{array}$ & 69.90 \\
\hline & & & & & & $\begin{array}{l}\text { Co-digestion of swine } \\
\text { manure and used } \\
\text { cooking grease }(2.5 \% \\
\text { by volume) }\end{array}$ & 0.73 & $\begin{array}{l}0.34^{\mathrm{x}} \\
0.31^{\mathrm{y}}\end{array}$ & $\begin{array}{l}0.46^{\mathrm{x}} \\
0.42^{\mathrm{y}}\end{array}$ & 66.90 \\
\hline & & & & & & $\begin{array}{l}\text { Co-digestion of swine } \\
\text { manure and used } \\
\text { cooking grease ( } 5 \% \text { by } \\
\text { volume) }\end{array}$ & 1.05 & $\begin{array}{l}0.29^{\mathrm{x}} \\
0.26^{\mathrm{y}}\end{array}$ & $\begin{array}{l}0.28^{\mathrm{x}} \\
0.24^{\mathrm{y}}\end{array}$ & 65.90 \\
\hline & & & & & & $\begin{array}{l}\text { Co-digestion of swine } \\
\text { manure and used } \\
\text { cooking grease (10\% } \\
\text { by volume) }\end{array}$ & 1.90 & $\begin{array}{l}0.35^{\mathrm{x}} \\
0.31^{\mathrm{y}}\end{array}$ & $\begin{array}{l}0.18^{\mathrm{x}} \\
0.16^{\mathrm{y}}\end{array}$ & 63.20 \\
\hline
\end{tabular}




\begin{tabular}{|c|c|c|c|c|c|c|c|c|c|c|}
\hline \multirow[t]{4}{*}{ [40] } & \begin{tabular}{|l|} 
Peru \\
2,800 \\
\end{tabular} & \multirow{4}{*}{$\begin{array}{|ll|}\text { Tubular } & \\
\text { polyethylene or } \\
\text { PVC }\end{array}$} & \multirow[t]{4}{*}{$<25$} & 7.5 & 90 & \multirow[t]{4}{*}{ Cow manure } & 0.22 & $\begin{array}{l}0.07^{\mathrm{z}} \\
0.06^{\mathrm{y}}\end{array}$ & $\begin{array}{l}0.32^{\mathrm{z}} \\
0.27^{\mathrm{y}}\end{array}$ & - \\
\hline & \begin{tabular}{|l|} 
Peru \\
3,300 \\
\end{tabular} & & & 7.5 & 90 & & - & - & - & $67^{\mathrm{w}}$ \\
\hline & \begin{tabular}{|l|} 
Peru \\
3,400 \\
\end{tabular} & & & 2.4 & 60 & & 1.29 & $\begin{array}{l}0.47^{\mathrm{z}} \\
0.43^{\mathrm{y}}\end{array}$ & $\begin{array}{l}0.36^{\mathrm{z}} \\
0.33^{\mathrm{y}}\end{array}$ & - \\
\hline & \begin{tabular}{|l|} 
Peru \\
3,900 \\
\end{tabular} & & & 6 & 100 & & - & - & - & $63^{w}$ \\
\hline [58] & \begin{tabular}{|l|} 
Peru \\
2,800 \\
\end{tabular} & Tubular PVC & $22-23$ & 7.5 & 75 & Guinea pig manure & 0.60 & $0.04^{\mathrm{y} \text { and } \mathrm{z}}$ & $0.06^{\mathrm{y} \text { and } \mathrm{z}}$ & $65^{\mathrm{w}}$ \\
\hline \multirow[t]{3}{*}{ [54] } & \multirow[t]{3}{*}{$\begin{array}{l}\text { Peru } \\
2,800\end{array}$} & \multirow[t]{3}{*}{ Tubular PVC } & \multirow[t]{3}{*}{$16-20$} & 7.5 & 90 & Cow manure & 0.34 & $\begin{array}{l}0.12^{\mathrm{z}} \\
0.11^{\mathrm{y}}\end{array}$ & $\begin{array}{l}0.36^{\mathrm{z}} \\
0.32^{\mathrm{y}}\end{array}$ & $55^{\mathrm{w}}$ \\
\hline & & & & 7.5 & 60 & Guinea pig manure & 1.01 & $0.03^{\mathrm{y} \text { and } \mathrm{z}}$ & $0.03^{\mathrm{y} \text { and } \mathrm{z}}$ & $60^{\mathrm{w}}$ \\
\hline & & & & 7.5 & 60 & $\begin{array}{l}\text { Co-digestion of Cow } \\
\text { (92.5\% by weight) and } \\
\text { guinea pig ( } 7.5 \% \text { by } \\
\text { weight) manure }\end{array}$ & 0.82 & $\begin{array}{l}0.08^{\mathrm{z}} \\
0.07^{\mathrm{y}}\end{array}$ & $\begin{array}{l}0.10^{\mathrm{z}} \\
0.08^{\mathrm{y}}\end{array}$ & $55^{\mathrm{w}}$ \\
\hline \multirow[t]{2}{*}{ [56] } & \multirow[t]{2}{*}{$\begin{array}{l}\text { Bolivia } \\
3,884\end{array}$} & \multirow[t]{2}{*}{$\begin{array}{l}\text { Tubular } \\
\text { polyethylene }\end{array}$} & \multirow[t]{2}{*}{$14-18$} & 0.85 & 124 & Cow manure & 0.24 & $0.06^{\mathrm{y}}$ & $0.23^{\mathrm{y}}$ & 47.22 \\
\hline & & & & 0.70 & 124 & $\begin{array}{l}\text { Cow manure and PET } \\
\text { rings }\end{array}$ & 0.24 & $0.09^{y}$ & $0.33^{y}$ & 47.54 \\
\hline \multirow[t]{6}{*}{ [69] } & $\begin{array}{l}\text { Bolivia } \\
3,831- \\
3,844 \\
\end{array}$ & \multirow[t]{6}{*}{$\begin{array}{l}\text { Tubular } \\
\text { polyethylene }\end{array}$} & \multirow[t]{6}{*}{$15-21$} & $\begin{array}{l}6.50 \\
(6)^{*}\end{array}$ & - & \multirow[t]{4}{*}{ Cow manure } & - & - & - & 46.50 \\
\hline & \begin{tabular}{|l|} 
Bolivia \\
2,628 \\
\end{tabular} & & & 7.30 & 118 & & 0.18 & $0.08^{y}$ & $0.44^{y}$ & 49.6 \\
\hline & \begin{tabular}{|l|} 
Bolivia \\
2,682 \\
\end{tabular} & & & 3.65 & 47 & & 0.52 & $0.09^{\mathrm{y}}$ & $0.17^{y}$ & - \\
\hline & \begin{tabular}{|l|} 
Bolivia \\
2,682 \\
\end{tabular} & & & 3.65 & 85.40 & & 0.37 & $0.09^{y}$ & $0.24^{y}$ & - \\
\hline & \begin{tabular}{|l|} 
Bolivia \\
2,607 \\
\end{tabular} & & & 6.47 & 34.11 & \multirow[t]{2}{*}{ Pig manure } & 1.15 & $0.25^{\mathrm{y}}$ & $0.22^{y}$ & 43.90 \\
\hline & \begin{tabular}{|l|} 
Bolivia \\
2,607 \\
\end{tabular} & & & \begin{tabular}{|l|}
12.90 \\
\end{tabular} & \begin{tabular}{|l|}
68.21 \\
\end{tabular} & & \begin{tabular}{|l|}
0.58 \\
\end{tabular} & $0.15^{\mathrm{y}}$ & $0.26^{\mathrm{y}}$ & 43.50 \\
\hline
\end{tabular}




\begin{tabular}{|c|c|c|c|c|c|c|c|c|c|c|}
\hline$[68]$ & \begin{tabular}{|l} 
Bolivia \\
3,884
\end{tabular} & $\begin{array}{l}\text { Tubular } \\
\text { polyethylene }\end{array}$ & 13-19 & 0.88 & 80 & Cow manure & 0.44 & $\begin{array}{l}0.09-0.12^{\mathrm{x}} \\
0.07^{\mathrm{y}}\end{array}$ & $\begin{array}{l}0.20-0.27^{\mathrm{x}} \\
0.17^{\mathrm{y}}\end{array}$ & 47.80 \\
\hline & & & & 0.84 & & Llama manure & & $\begin{array}{l}0.11-0.14^{\mathrm{x}} \\
0.10^{\mathrm{y}}\end{array}$ & $\begin{array}{l}0.25-0.32^{\mathrm{x}} \\
0.22^{\mathrm{y}}\end{array}$ & 46.70 \\
\hline & & & & 0.86 & & $\begin{array}{l}\text { Co-digestion of cow } \\
\text { and sheep manure }\end{array}$ & & $\begin{array}{l}0.17-0.28^{\mathrm{x}} \\
0.015^{\mathrm{y}}\end{array}$ & $\begin{array}{l}0.39-0.64^{\mathrm{x}} \\
0.34^{\mathrm{y}}\end{array}$ & 44.80 \\
\hline & & & & 0.86 & & $\begin{array}{l}\text { Co-digestion of llama } \\
\text { and sheep manure }\end{array}$ & & $\begin{array}{l}0.06^{\mathrm{x}} \\
0.05^{\mathrm{y}}\end{array}$ & $\begin{array}{l}0.15^{\mathrm{x}} \\
0.11^{\mathrm{y}}\end{array}$ & 45.60 \\
\hline$[72]$ & $\begin{array}{l}\text { Colombia } \\
1,850\end{array}$ & $\begin{array}{l}\text { Tubular PVC and } \\
\text { polyethylene }\end{array}$ & $22-25$ & $\begin{array}{l}0.52 \\
(2)^{*}\end{array}$ & 15 & $\begin{array}{l}\text { Co-digestion of pig } \\
\text { manure and urine }\end{array}$ & - & $\begin{array}{l}0.19^{\mathrm{x}} \\
0.14^{\mathrm{y}}\end{array}$ & - & - \\
\hline
\end{tabular}

[33] Ferrer et al., 2009; [65] Chao et al., 2008; [16] Lansing et al., 2008; [31] Lansing et al., 2008; [66] Lansing et al., 2010; [67] Lansing et al.,2010; [40] Ferrer et al., 2011;

[58] Garfí et al., 2011; [54] Garfí et al., 2011; [56] Martí-Herrero et al., 2014; [69] Martí-Herrero et al., 2015; [68] Martí-Herrero et al., 2015; [72] Pedraza et al., 2002. HRT:

hydraulic residence time; OLR: organic loading rate. * Number of digesters monitored; ** Calculated as the $80 \%$ of total volume. Biogas volumes expressed: (x) in local

conditions; (y) at $0{ }^{\circ} \mathrm{C}$ and $1 \mathrm{~atm} ;(\mathrm{z})$ at $20^{\circ} \mathrm{C}$ and $1 \mathrm{~atm}$. (w): estimated by $\mathrm{CO}_{2}$ content 
Table 5. Average feedstock (before dilution) and digestate characteristics for the most common substrates in Latin America.

\begin{tabular}{|c|c|c|c|c|c|c|c|c|c|c|c|c|c|}
\hline Substrate & TS (\%) & $\begin{array}{c}\text { VS } \\
(\% \mathrm{TS})\end{array}$ & \multicolumn{2}{|c|}{$\begin{array}{c}\text { TKN } \\
(\% \mathrm{TS})\end{array}$} & \multicolumn{2}{|c|}{$\begin{array}{l}\mathrm{N}-\mathrm{NH}_{4} \\
(\% \mathrm{TS})\end{array}$} & \multicolumn{2}{|c|}{$\begin{array}{l}\mathbf{P}_{-P_{2} \mathbf{O}_{5}} \\
(\% \mathrm{TS})\end{array}$} & \multicolumn{2}{|c|}{$\begin{array}{l}\mathrm{K}-\mathrm{K}_{2} \mathrm{O} \\
(\% \mathrm{TS})\end{array}$} & pH & $\begin{array}{c}\mathrm{EC} \\
\mu \mathrm{S} \mathrm{cm} \mathrm{cm}^{-1}\end{array}$ & References \\
\hline $\begin{array}{l}\text { Cow } \\
\text { manure }\end{array}$ & $\begin{array}{l}13.42- \\
19.80\end{array}$ & $\begin{array}{l}61.72- \\
91.39\end{array}$ & \multicolumn{2}{|c|}{$1.28-2.62$} & \multicolumn{2}{|c|}{$0.05-3.78$} & \multicolumn{2}{|c|}{$0.23-1.17$} & \multicolumn{2}{|c|}{$0.06-1.65$} & $\begin{array}{l}7.10- \\
8.58\end{array}$ & 10.16 & {$[40,53,54,56,61,62,63,64]$} \\
\hline $\begin{array}{c}\text { Guinea pig } \\
\text { manure }\end{array}$ & $\begin{array}{l}25.96- \\
27.82\end{array}$ & $\begin{array}{l}67.61- \\
68.51\end{array}$ & \multicolumn{2}{|c|}{$0.83-0.94$} & \multicolumn{2}{|c|}{$0.10-1.64$} & \multicolumn{2}{|c|}{$0.12-0.39$} & \multicolumn{2}{|c|}{$0.43-1.45$} & $\begin{array}{l}8.79- \\
8.82\end{array}$ & $\begin{array}{l}17.38- \\
17.95\end{array}$ & {$[54,58,71]$} \\
\hline $\begin{array}{l}\text { Llama } \\
\text { manure }\end{array}$ & $\begin{array}{l}49.50- \\
67.00\end{array}$ & $\begin{array}{l}64.40- \\
74.40\end{array}$ & \multicolumn{2}{|c|}{$1.70-1.90$} & \multicolumn{2}{|c|}{0.14} & \multicolumn{2}{|c|}{$0.40-0.70$} & \multicolumn{2}{|c|}{$1.10-1.50$} & 7.8 & - & {$[53,61,62,64]$} \\
\hline \multirow[t]{2}{*}{ Digestate } & TS & VS & \multicolumn{2}{|c|}{ TKN } & \multicolumn{2}{|c|}{$\mathrm{N}-\mathrm{NH}_{4}$} & \multicolumn{2}{|c|}{$\mathbf{P}-\mathbf{P}_{2} \mathrm{O}_{5}$} & \multicolumn{2}{|c|}{$\mathbf{K}-\mathbf{K}_{2} \mathbf{O}$} & pH & EC & References \\
\hline & $(\%)$ & $(\% \mathrm{TS})$ & (\% TS) & $\begin{array}{c}\left(\mathrm{mg} \mathrm{L}^{-}\right. \\
\mathbf{1}^{-}\end{array}$ & $(\% \mathrm{TS})$ & $\begin{array}{c}\left(\mathrm{mg} \mathrm{L}^{-}\right. \\
\mathbf{1}^{-}\end{array}$ & (\%TS) & $\left(\mathrm{mg} \mathrm{L}^{-1}\right)$ & $(\% \mathrm{TS})$ & $\begin{array}{c}\left(\mathrm{mg} \mathrm{L}^{-}\right. \\
\mathbf{1}^{-}\end{array}$ & & $\mu \mathrm{S} \mathrm{cm}$ & \\
\hline Cow & $0.89-2.69$ & $\begin{array}{l}64.43- \\
65.88\end{array}$ & 3.05 & 271 & 1.86 & 165.50 & 1.51 & 134.50 & 1.89 & 168 & $\begin{array}{l}7.10- \\
7.20\end{array}$ & 5.77 & {$[54,56,63]$} \\
\hline Guinea pig & $0.63-0.70$ & $\begin{array}{l}42.35- \\
46.87\end{array}$ & $\begin{array}{l}2.93- \\
5.44\end{array}$ & $\begin{array}{l}185- \\
380\end{array}$ & $\begin{array}{l}2.88- \\
3.09\end{array}$ & $190-210$ & $\begin{array}{l}2.08- \\
3.62\end{array}$ & $130-215$ & $\begin{array}{l}3.58- \\
10.38\end{array}$ & $\begin{array}{l}250- \\
730\end{array}$ & $\begin{array}{l}7.10- \\
7.30\end{array}$ & $6.88-8.30$ & {$[54,58,71]$} \\
\hline Llama & - & 54.61 & - & - & - & - & - & - & - & - & $\begin{array}{l}7.20- \\
7.50\end{array}$ & - & {$[62,63]$} \\
\hline
\end{tabular}

[40] Ferrer et al., 2011; [53] Alvarez, and Lidén, 2008; [54] Garfí et al., 2011; [56] Martí-Herrero et al, 2014; [58] Garfí et al., 2011; [61] Alvarez et al., 2006; [62] Alvarez,

and Lidén, 2008; [63] Alvarez, and Lidén, 2009; [64] Alvarez, and Lidén, 2008; [71] Garfí et al., 2011. TS: Total Solids; VS: Volatile Solids; TKN: Total Kjeldahl nitrogen;

$\mathrm{N}-\mathrm{NH}_{4}$ : Ammonium nitrogen; $\mathrm{P}-\mathrm{P}_{2} \mathrm{O}_{5}$ : Phosphorus; $\mathrm{K}-\mathrm{K}_{2} \mathrm{O}$ : Potassium; EC: Electrical conductivity. 
(a)

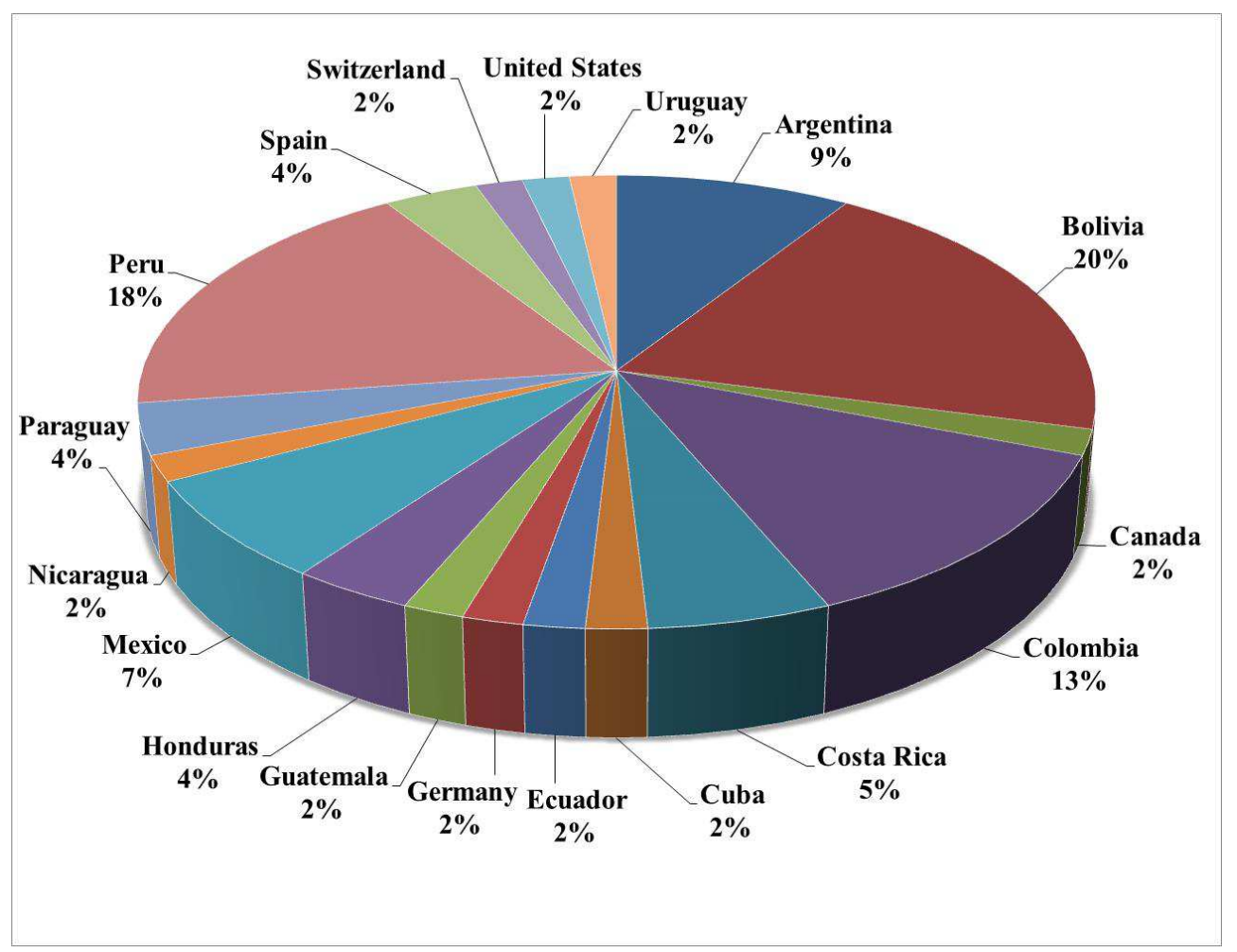

(b)

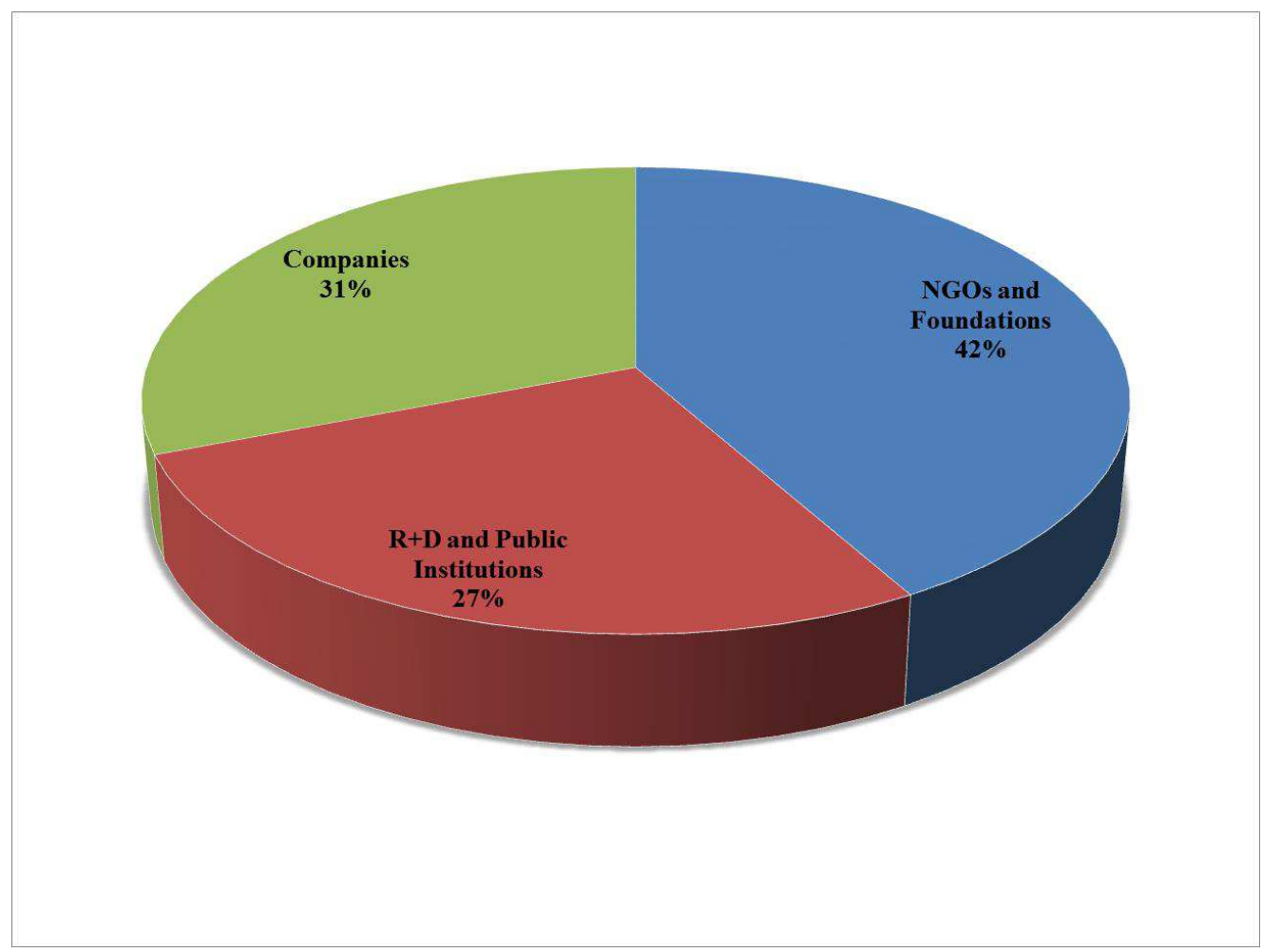

Figure 1. Percentage of institutions per country (a) and type of institutions (b) in RedBioLAC (data from RedBioLAC database [41], last update January 2015) 


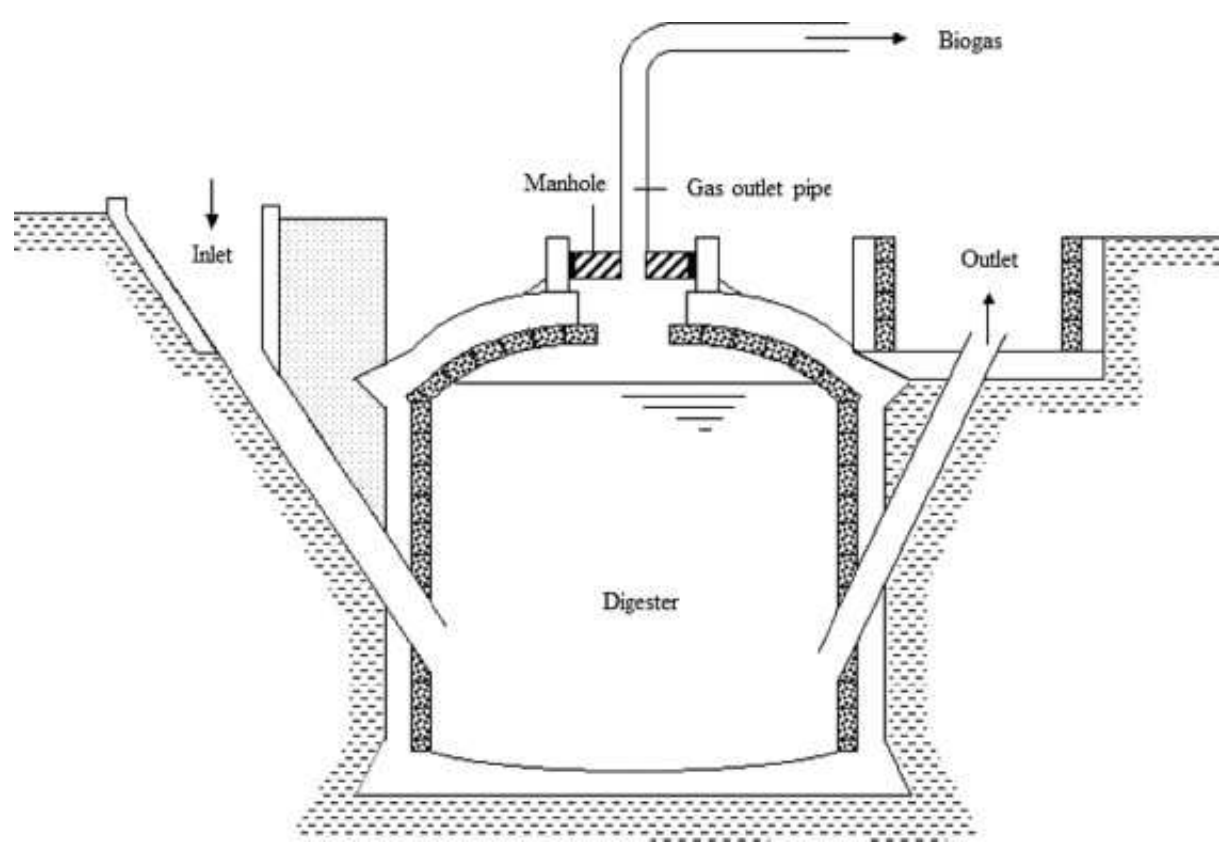

(a)

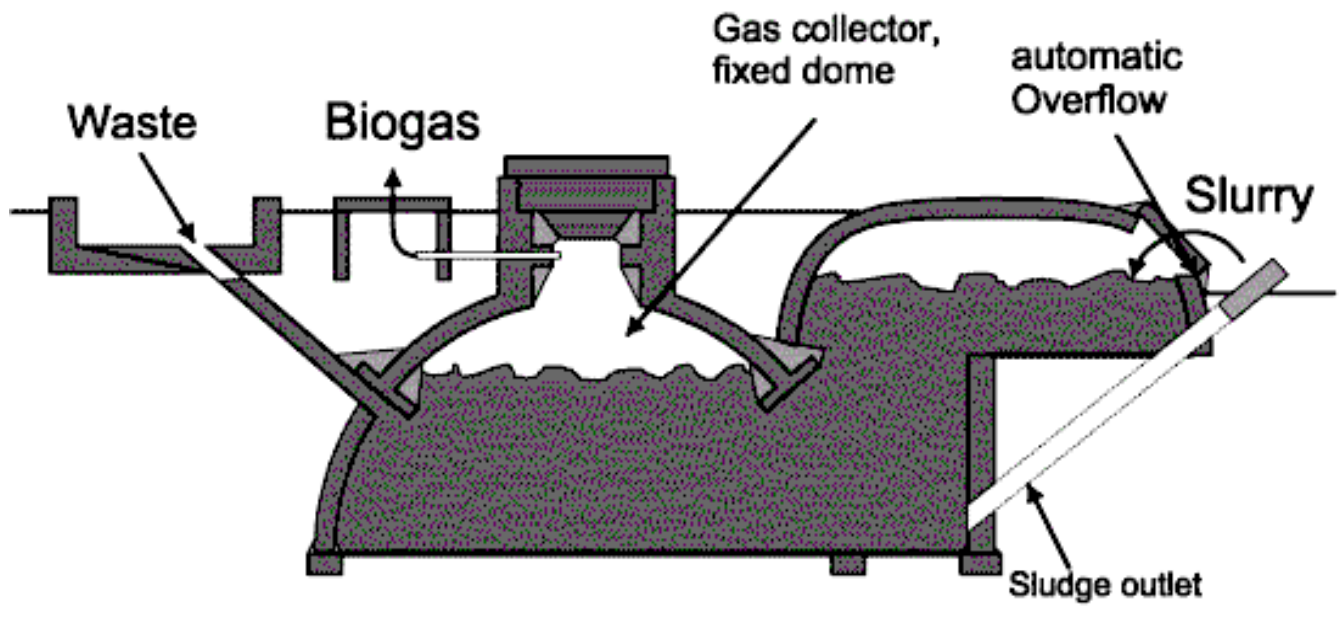

(b)

Figure 2. Schematic diagram of fixed dome digesters: (a) fixed dome - Chinese model $[23,51]$ and (b) Camartec model [48] 


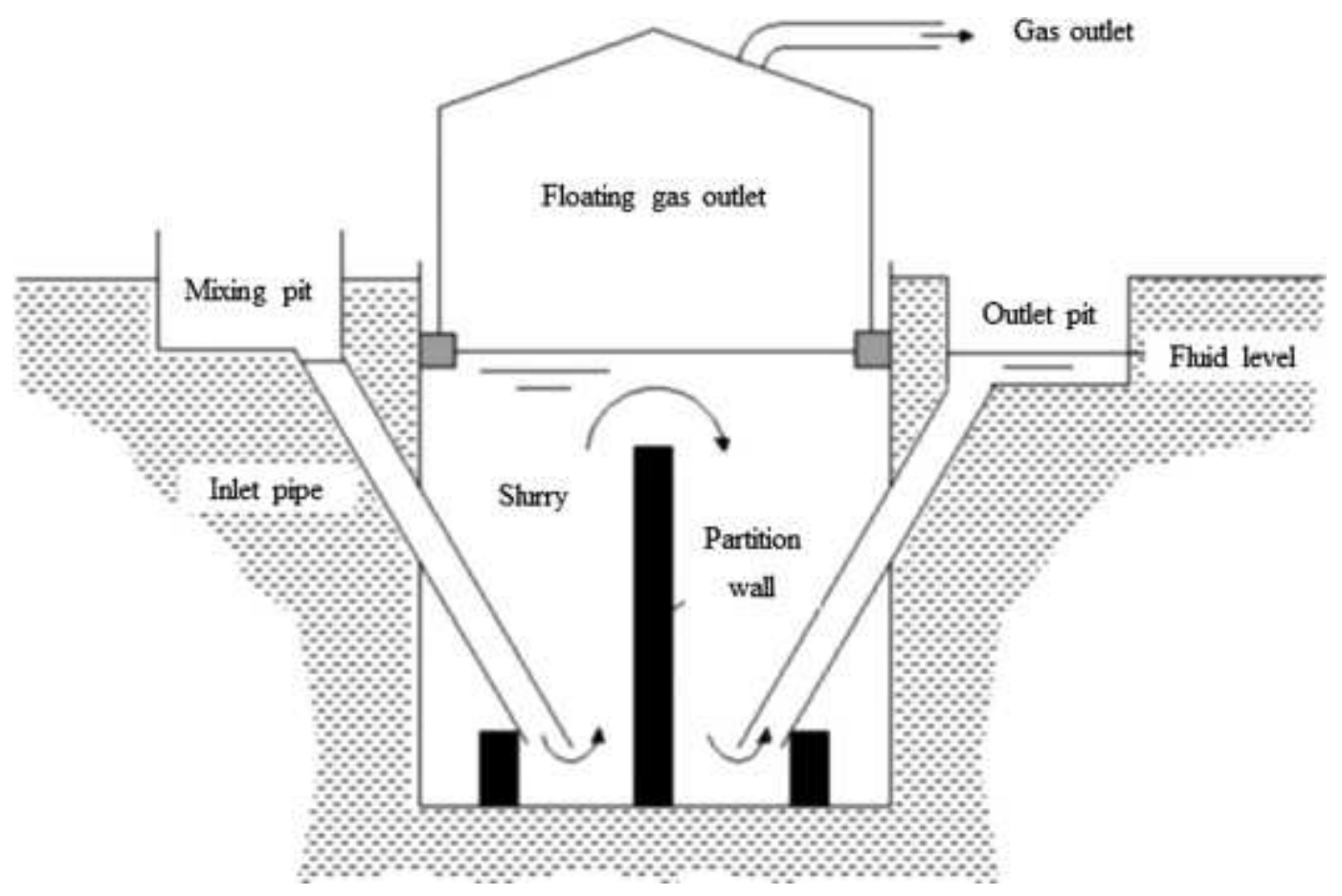

Figure 3. Schematic diagram of floating drum - Hindu style model $[23,51]$ 
(a)

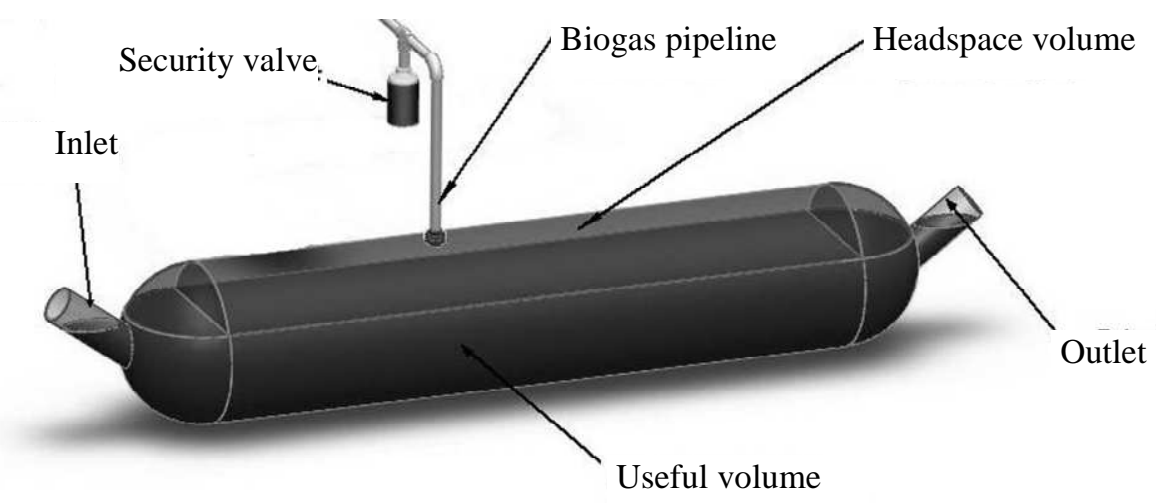

(b)

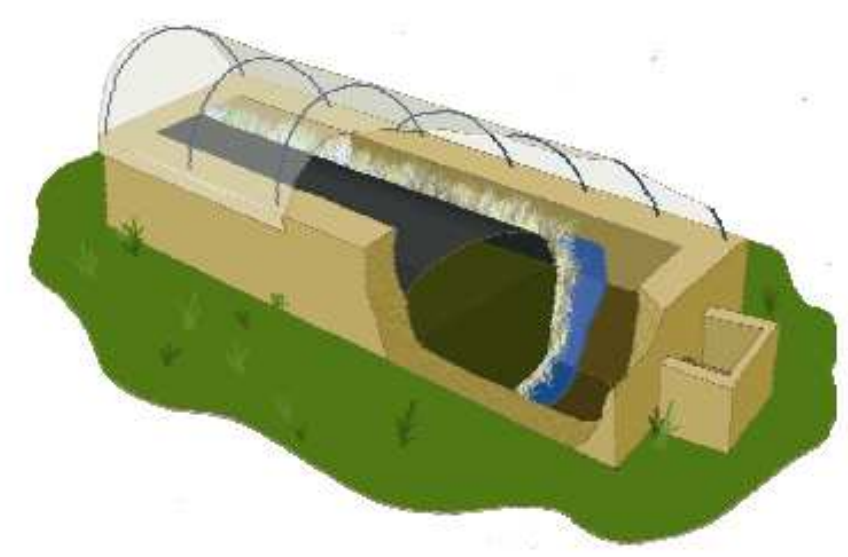

Figure 4. Tubular digester model: a) schematic of the systems; b) adaptation to Andean Plateau (dome roof) (courtesy of Blanca Corona from Ingeniería sin Fronteras Zaragoza) 